IZA DP No. 1275

Migration and Labour Market Differences: The Case of Wales

Stephen Drinkwater

David Blackaby

August 2004 


\title{
Migration and Labour Market Differences: The Case of Wales
}

\author{
Stephen Drinkwater \\ University of Surrey, \\ WELMERC, University of Wales Swansea, \\ and IZA Bonn \\ David Blackaby \\ WELMERC, University of Wales Swansea, \\ and University of Swansea
}

Discussion Paper No. 1275

August 2004

\author{
IZA \\ P.O. Box 7240 \\ 53072 Bonn \\ Germany
}

Phone: +49-228-3894-0

Fax: +49-228-3894-180

Email: iza@iza.org

\begin{abstract}
Any opinions expressed here are those of the author(s) and not those of the institute. Research disseminated by IZA may include views on policy, but the institute itself takes no institutional policy positions.

The Institute for the Study of Labor (IZA) in Bonn is a local and virtual international research center and a place of communication between science, politics and business. IZA is an independent nonprofit company supported by Deutsche Post World Net. The center is associated with the University of Bonn and offers a stimulating research environment through its research networks, research support, and visitors and doctoral programs. IZA engages in (i) original and internationally competitive research in all fields of labor economics, (ii) development of policy concepts, and (iii) dissemination of research results and concepts to the interested public.
\end{abstract}

IZA Discussion Papers often represent preliminary work and are circulated to encourage discussion. Citation of such a paper should account for its provisional character. A revised version may be available directly from the author. 
IZA Discussion Paper No. 1275

August 2004

\section{ABSTRACT \\ Migration and Labour Market Differences: The Case of Wales*}

The migration of labour can affect economies in several ways. This paper focuses on two of the economic impacts of migration in the context of the recent Welsh experience. Firstly, since migration is a key aspect of labour market flexibility, it is a mechanism through which local and regional labour market differences can be reduced. However, it is found that the most deprived parts of Wales have the lowest levels of migration and that both in and outmigration rates are negatively correlated with unemployment and sickness rates. Secondly, the characteristics of in and out-migrants have important implications for the current and future performance of local and regional economies. Using a variety of data sources, it is shown that people leaving Wales are younger and more educated than migrants to Wales. Furthermore, younger and more educated Welsh individuals appear to have a higher willingness to move than their counterparts living elsewhere in Britain.

JEL Classification: J61, R23

Keywords: migration, local and regional labour markets, Wales

Corresponding author:

Stephen Drinkwater

Department of Economics

University of Surrey

Guildford

Surrey GU2 7XH

United Kingdom

Email: s.drinkwater@surrey.ac.uk

\footnotetext{
* The British Social Attitudes Survey and the Quarterly Labour Force Survey were obtained from the Data Archive at the University of Essex. The Sample of Anonymised Records is Crown Copyright. We would also like to thank Nigel O'Leary for helpful discussions and participants at the Royal Economic Society Annual Conference at Swansea for useful comments. All remaining errors are the responsibility of the authors.
} 


\section{Introduction}

Population migration has many economic implications and hence the economic analysis of migration has grown substantially in recent years (Borjas, 1994; 1999, Greenwood, 1997). At the individual level, migration can improve the welfare of the migrant and their family, particularly if they originate from a low wage or low employment area. At a more aggregate level, given that the migration of labour is a key component of labour market flexibility, it is a mechanism through which local and regional labour market differences can be reduced. Migration can also affect the population structure of local areas. For example, certain areas may lose a disproportional share of their younger and educated workers, whilst others may mainly attract retired individuals. These movements can thus affect the current and future prosperity of an area as well as the demand for and provision of local services and amenities.

In this paper we examine the trends in and implications of migration to, from and within Wales, as well as analyzing the characteristics of migrants and attitudes towards migration. Wales provides an interesting case study because it has historically seen periods of considerable in and out migration (Thomas, 1930; Daniel, 1940). This is most clearly demonstrated by the fact that of the four countries that constitute the United Kingdom (UK), Wales has by far the most diverse population, as measured by the percentage of individuals born outside the country. According to figures from the 2001 Census, around a quarter of the Welsh population were born outside Wales, compared to only 13 per cent of the English and Scottish populations and 9 per cent of the population of Northern Ireland. A high proportion of Welsh-born individuals also leave the country, with 22 per cent of the Welsh-born population who lived in the UK in 2001 residing outside the country of their birth. The respective percentages for the 
Scots, Northern Irish and English born were 16 per cent, 14 per cent and 2 per cent. It is also found that migrants are not evenly distributed across Wales and that migration is highly correlated with labour market variables. However, rather than people from deprived areas being more willing to migrate, there appears to be a strong negative relationship between an area's in and out-migration rates and its unemployment and sickness rates.

The paper begins by reviewing the literature on the link between migration and labour market differentials. Section 3 contains an analysis of spatial labour market differences in the UK and recent trends in migration to, from and within Wales. This is followed by an examination of the characteristics of the different migrant groups, focusing specifically on age and human capital considerations. An econometric model of migrant status is then estimated to highlight differences between the migrant groups. An attempt is also made to identify the characteristics of those who are most likely to migrate by examining information on individuals' willingness to move varying distances. Section 5 contains a summary and some policy implications.

\section{The impact of migration on regional labour markets}

The principle market response for correcting local and regional economic disparities is migration. The migration that takes place could either apply to that of labour and/or of firms. Classical economic theory would predict that this mechanism should be effective in reducing regional imbalances. A movement of labour from a deprived to a prosperous area reduces labour supply in the former and increases it in the latter, thereby reducing wage and unemployment differentials. Alternatively, a movement of firms in the opposite direction would cause labour demand to increase in the deprived area, thus raising relative wages and employment in the deprived area. 
These predictions also hold in a dynamic setting, as shown by Möller (2001), who develops a theoretical framework to analyse regional adjustment dynamics. The dynamic wage setting and unemployment equations for region $r$ that Möller (2001) derives are:

$$
\begin{gathered}
\dot{w}_{r}=-\eta_{1}\left(w_{r}-p_{r}\right)+\eta_{1}\left(a_{r}+g_{r}\right)-\eta_{2} u_{r}-\eta_{3} q_{r}+x_{r}^{w} \\
\dot{u}_{r}=-\left(\lambda_{1}+v_{1}\right) u_{r}+\left(\lambda_{2}+v_{3}\right)\left(w_{r}-p_{r}\right)+v_{1} l_{r}-v_{2} y_{r}-\xi_{1} q_{r}+\left(v_{2}-v_{3}\right) a_{r}+\lambda_{2} g_{r}+x_{r}^{u}
\end{gathered}
$$

where $w_{r}$ is the nominal wage, $p_{r}$ is the price index for tradable production goods, $a_{r}$ is total factor productivity, $g_{r}$ is the price gap between the production and consumption wage, $y_{r}$ is production, $u_{r}$ is the unemployment rate, $q_{r}$ is the participation rate and $l_{r}$ is the potential labour supply. These are all endogenous variables, whereas $x_{r}^{w}$ and $x_{r}^{u}$ represent the influence of exogenous structural variables on wage setting and unemployment. The two equations refer to growth rates and can be approximated by $\log$ differences. The equations show that the dynamic development of unemployment in region $r$ depends positively on labour supply and negatively on participation, whilst wage rate dynamics are negatively related to both unemployment and participation. This implies that a net out-migration of labour from a deprived region will raise relative wages and reduce unemployment.

However, the real world is far more complicated than the classical models would predict, mainly because they are based on several restrictive assumptions (Armstrong and Taylor, 2000). These include perfect competition, no barriers to mobility (e.g. no migration costs), perfect information, homogeneous factors of production and perfectly flexible factor prices. There are therefore many reasons to believe why both labour and capital will be relatively immobile across space. In particular, firms do not 
appear to move to areas where labour is cheaper (Armstrong and Taylor, 2000). This can be explained by the strong geographical inertia displayed by firms as a result of location specific input-output linkages and key personnel.

Individuals may also be unwilling to move from one region to another even if other areas offer substantially higher wages or better employment prospects. Costs are very important in this respect since it is likely that the individual will incur both pecuniary and non-pecuniary costs as a result of their move and these may be large enough to outweigh the potential gains on offer. An important pecuniary cost of migrating is the cost of buying a house. For example, it is highly unlikely that an unemployed individual in the North East could afford to speculatively move their family to the South East where their employment opportunities and future earnings power are likely to be higher. Non-pecuniary or psychological costs are also likely to be large for individuals with a strong attachment to the area where they currently reside especially if all of their friends and family live locally. Search costs can also be important since individuals tend to be imperfectly informed about employment opportunities in other areas. However, information flows are likely to have improved in recent years with technological developments such as the advent of the internet.

If the market is unsuccessful in reducing regional imbalances then the government can play a role in assisting these movements, particularly firm relocation, through its regional policy. ${ }^{1}$ However, regional policy in the UK has been dramatically scaled down over the past two decades. For example, Regional Selective Assistance (RSA) -

\footnotetext{
${ }^{1}$ Previous UK governments have also tried to stimulate labour migration. For example, the Industrial Transference Scheme, which was introduced in 1928, gave grants and loans to unemployed migrants. This was followed by a number of other schemes which tried to boost labour mobility but these were phased out because they were deemed not to be cost effective. For further details of these schemes and a history of regional policy in the UK, see Scott (2004).
} 
the main domestic policy instrument over the period - was considerably lower in nominal terms in 1999/2000 than it was in $1990 / 1 .^{2}$ RSA also tends to focus more on attracting foreign direct investment rather than trying to induce domestic firms to relocate (Armstrong and Taylor, 2000). There has also been an increasing reliance on EU regional funding over the last two decades, with the current amount of EU funding currently more than double that of $\mathrm{RSA}^{3}$ However, with the accession of ten relatively poor economies to the EU in May 2004, regional assistance to the current member states may not be so generous in future. This implies that despite the factors that inhibit the movement of the labour, it has been, and may increasingly be, left to the market to assume a more prominent role if local and regional inequalities are to be reduced.

There is also some debate over the degree of convergence between regional economies that actually results from increased migration. Barro and Sala-i-Martin (1991) and Blanchard and Katz (1992) do provide some evidence that migration has reduced regional income and unemployment differentials in the US. Despite the relatively large internal migration flows in the US, Borjas (2001) argues that these movements are insufficient to ensure the rapid elimination of income differentials and immigration can improve labour market efficiency since new immigrant workers will tend to locate in high wage areas. ${ }^{4}$ It follows that given the smaller volume of both internal and international migration in the UK then it will take far longer to remove regional differentials. Pissarides and McMaster (1990) argue that the adjustment process brought about by regional migration is slow and estimate that it takes over 20

\footnotetext{
${ }^{2}$ See Wren (1996) for a discussion of the reduction in regional assistance in the UK over a longer period.

${ }^{3}$ See Drinkwater (2003) for further details.

${ }^{4}$ Borjas (2001) estimates that the efficiency gain which accrues to US natives through the equalisation of the value of marginal products of workers in different labour markets as a result of immigration is subsantial. His simulations suggest that this gain is in the order of $\$ 5$ billion to $\$ 10$ billion per annum.
} 
years to remove a disequilibrium unemployment differential in a depressed region. Hughes and McCormick (1994) and McCormick (1997) find that migration had only a limited impact on reducing the north-south divide. ${ }^{5}$ Part of the explanation for these findings is that migration tends to be pro-cyclical, which implies that migration is not likely to be a very effective mechanism for reducing regional unemployment differentials, especially during recessions (Armstrong and Taylor, 2000). Decressin and Fatás (1995) find that for Europe, participation rates fall rather than there being a tendency for individuals to migrate in response to an economic shock.

From the above discussion, it can be seen that migration has a potentially important role to play in reducing spatial labour market differences. However, some of the empirical evidence suggests that the volume of migration seen in many developed countries is insufficient to narrow these differentials. Furthermore, the respective characteristics of those people moving to an area compared to those who leave should also be considered. Age and human capital are particularly important in this respect given that these factors are important determinants of both current and future economic performance. Therefore, the proceeding analysis not only considers the relationship between migration and labour market variables but also the characteristics of migrants, focusing in particular on their age and education.

\footnotetext{
${ }^{5}$ See Armstrong and Taylor (2000) for a summary of evidence from other countries.
} 


\section{Spatial labour market differences and migration to, from and within Wales}

\subsection{UK regional labour market differences}

Spatial economic inequalities were present in the UK for the majority of the twentieth century. For example, Scott (2004) reports that in 1951 the unemployment rate in Wales was over three times as high as it was in the South East, whilst Gross Domestic Product (GDP) per capita in Wales was just 84 per cent of the UK average. Wide regional disparities continued to be observed at the end of the 1970s despite the relatively generous regional assistance that had been allocated to deprived areas in the preceding decades. There was also clear evidence of a north-south divide in earnings and unemployment during the 1980s, even after controlling for socio-economic and demographic factors (Blackaby and Manning, 1990; Blackaby and Murphy, 1995).

However, regional unemployment rates have converged since the early 1990s. ${ }^{6}$ The narrowing of regional unemployment rates is clearly demonstrated by the information presented in Table 1. In particular, the statistics indicate that regional unemployment differences are now very small. By 2002, the International Labour Organisation (ILO) unemployment rate for the UK had fallen to 5.2 per cent, with no region experiencing an unemployment rate in excess of 7 per cent. There has also been a convergence in the duration of unemployment spells across regions during the 1990s. Most notably, the percentage of claimants who were unemployed for more than one year in Northern Ireland was substantially lower, whilst in general, the remainder of the regions were clustered around the UK average. ${ }^{7}$

\footnotetext{
${ }^{6}$ Martin (1997) discusses the evolution of regional unemployment rates in the UK since the 1960s and the reduction in the differentials that took place during the recession of the early 1990s.

${ }^{7}$ See Drinkwater (2003) for further details.
} 
However, despite the ILO definition being a more preferable measure of unemployment than the claimant count definition, the employment situation is not as healthy as the ILO figures would suggest. This is because even though the ILO captures an individual's willingness to work rather than whether they claim benefit, it does not capture hidden unemployment caused by inactivity, which is particularly high in some of the peripheral regions. With large numbers of unemployment benefit claimants transferring to invalidity benefit, the published unemployment figures can grossly underestimate the 'real' level of unemployment in some areas (Fothergill, 2001). It can be seen from Table 1 that employment rates (which measure numbers in employment as a percentage of the working age population) are particularly low in the North East, Northern Ireland and Wales, where less than 70 per cent of working age individuals were in employment in 2002, compared to over 80 per cent in the South East. $^{8}$

Table 1 also reports wide regional variation in terms of earnings and income. In particular, the peripheral regions lag well behind those in the south in terms of average earnings, with these differentials tending to have increased over the 1990s. London stands out as the region with the highest earners, but earnings are also relatively high in the surrounding South East and Eastern regions. Cameron and Muellbauer (2000) argue that the Office of National Statistics (ONS) figures are even an underestimate of the true earnings differential. Although it should of course be acknowledged that prices, and house prices in particular, are much higher in London and the South East. Hence cost of living differences could remove a significant

\footnotetext{
${ }^{8}$ It should be noted that the North East, Wales and Northern Ireland have historically experienced relatively high levels of unemployment.
} 
proportion of the earnings advantage enjoyed by some of those living in London and the South East.

Due to the large number of individuals claiming state benefits in some regions and hence differences in the proportion of tax payers, per capita disposable household income may be a more appropriate indicator with which to consider regional income differentials. When this variable is expressed as a percentage of the national average, it is lower than the equivalent earnings figure for some regions, most notably the North East, where disposable household income is less than 83 per cent of the UK figure. In addition, disposable household income in Scotland and the South West fell relative to the national average during the 1990s. Linacre (2002) also reports substantial variation in the composition of household income across the UK. For example, the compensation of employees accounts for 62 per cent and benefits only 6 per cent of household income in Swindon, compared to 47 per cent and 17 per cent in the North of Northern Ireland and 41 per cent and 10 per cent in South West Wales respectively.

Regional income inequality is even more acute if GDP differentials are considered. For example, GDP per capita was 77.3 per cent, 77.5 per cent and 80.5 per cent of the UK average in 1999 in the North East, Northern Ireland and Wales respectively. The existence of deprived areas in the UK is further highlighted by the fact that several areas are now eligible for Objective 1 funding as a consequence of their GDP per capita being less than 75 per cent of the European Union (EU) average. From 2000, the areas that are able to attract this type of funding are Merseyside, South Yorkshire, West Wales and the Valleys, Cornwall and the Isles of Scilly. 


\subsection{UK inter-regional migration flows}

Even though the peripheral regions have typically been net exporters of people over the period, it can be seen that by comparing the migration flows in Table 2 to the population figures reported in Table 1 that only a small proportion of individuals actually move region each year. The table also shows that London has the largest net population outflow in each of the years. The main recipients of this outflow have been the South West, South East and the Eastern region. The latter two regions have mainly benefited from the outward movement of London workers to the commuter belt, while the former has traditionally been a magnet for pensioners, The East Midlands has also seen quite a large level of net in-migration in recent years, while other English regions have typically experienced a small amount of net migration. Gordon and Molho (1998) document how these patterns have generally been observed over a longer time period and discuss the issues that arise in greater detail. However, London attracts a large number of immigrants, which offsets the out-migration of residents to other parts of the country. According to the ONS, immigration to London in 2000 amounted to 223,000 , which accounted for around 45 per cent of immigrants who entered the UK in that year.

Wales is also a net importer of migrants from the rest of the UK. Table 2 shows that the inflow of migrants to Wales has grown considerably in recent years, from around 45,000 in 1981 to 64,000 in 2002 . On the other hand, the number of out-migrants from Wales to other parts of the UK has remained around the 50,000 mark since the mid-1980s. Part of the reason for the net inflow of people into Wales is that its rural areas provide an attractive location for retirement. However, in 2000 there was also a net inflow of 1,200 and 4,000 individuals in the 25-44 and 45-64 age groups respectively. A more detailed analysis of the age composition of Welsh migration will 
be undertaken in Section 4.1. It can also be seen from Table 2 that despite having a total population of less than 60 per cent of that of Scotland, the absolute amount of people entering Wales from other parts of the UK has typically been far higher than the respective figure for Scotland. In contrast, the numbers leaving Wales and Scotland for other parts of the UK have been roughly equal over the last couple of decades.

\subsection{Spatial labour market differences within Wales}

Some of the labour market trends that have occurred at the UK level are also observed when local labour markets within Wales are analysed. In particular, Table 3 reports that most Welsh Unitary Authorities (UAs) have unemployment rates that do not differ greatly from the Welsh average. ${ }^{9}$ Although unemployment rates have fallen considerably in the South Wales Valleys over the past two decades, the highest unemployment rates in Wales still tend to be found in this area. For example, three out of the four UAs with unemployment rates of 7 per cent or more in 2002 were located in the Valleys (Blaenau Gwent, Merthyr Tydfil and Neath Port Talbot), the other high unemployment area being Anglesey.

It was noted in the previous section that hidden unemployment due to high levels of economic inactivity is a particular problem in Wales and further evidence of this is provided in Table 3. Furthermore, it is again the South Wales Valleys where the lowest employment rates are to be found, with the three Valley UAs with relatively high unemployment suffering from extremely low employment rates since just over a half of the working age populations in these areas were in employment. The growth in inactivity rates has been greatest in traditional high unemployment areas and where

\footnotetext{
${ }^{9}$ The geographic location of the Welsh UAs is shown in Figure 1.
} 
employment growth has been slowest. The primary reason for the rise in inactivity rates in Wales is the large percentage of working individuals claiming invalidity benefits because of the relative generosity of these payments in comparison to unemployment benefits (Webster, 2000). Inactivity and long term sickness are highly concentrated in the former mining communities of the South Wales Valleys, with over 15 per cent of adults in Merthyr Tydfil defined as permanently sick and slightly lower percentages observed in Blaenau Gwent, Neath Port Talbot, Caerphilly and Rhondda Cynon Taff. One startling statistic from the 2001 Census summarises this problem. Of the 100 (out of the 8868) wards England and Wales with the highest incidence of long term sickness, 63 were located in Wales, including two out of the top three and ten out of the top twenty.

Table 1 showed that earnings in Wales were only 87 per cent of the national average in 2003 and even within Wales there is quite high variation. It can be seen from Table 3 that in this year wages were above the British average in only two Welsh UAs, Monmouthshire and the Vale of Glamorgan. Wages in the South Wales Valleys are well below the Welsh average, with Blaenau Gwent the only UA in 2003 where gross earnings were less than $£ 9$ an hour.

\subsection{Migration to, from and within Welsh UAs}

Table 4 reports migration rates within Welsh UAs, to the UA from other parts of the UK, from outside the UK and from the UA to elsewhere in the UK. ${ }^{10}$ It is noticeable that the Welsh UAs with the highest migration rates in 2001 were those in the rural west and north. Ceredigion in particular has a high migration rate, since it has the highest percentage of its population moving within its boundaries, as well as the

\footnotetext{
${ }^{10}$ The percentage with no previous address is also recorded.
} 
highest rate of inward and outward migration to and from other parts of the UK. Cardiff has the second highest migration rate and also attracts the highest percentage of its population of any Welsh UA from overseas. This is not surprising given the capital's relatively diverse population base and local economy. The least dynamic areas in terms of mobility are the Valley UAs of Merthyr Tydfil, Torfaen and Blaenau Gwent.

Table 5 presents details of the composition of the population of Welsh UAs in terms of their country of birth. Information on the country of birth for the residents of England, Scotland and Northern Ireland in 2001 is also included for comparative purposes. The table shows that Wales has by far the most diverse population of the four countries that make up the UK in terms of country of birth. ${ }^{11}$ Just over threequarters of Welsh residents in 2001 were born in Wales, whereas over 87 per cent of the English and Scottish populations were born in those countries and more than 91 per cent of people living in Northern Ireland were born there. Over 80 per cent of the Welsh population born outside the country were born in England, with people born outside of the EU contributing the next highest proportion of immigrants to Wales. There has been a roughly proportional movement of the Welsh born to other parts of the UK since over 20 per cent of people born in Wales now live in England (ONS, 2004). On the other hand, people born in Scotland, Northern Ireland, the Irish Republic and the EU each accounted for less than 1 per cent of the Welsh population.

A further indication of the degree of cumulative migration (from outside Wales) can be obtained at the UA level using the country of birth data. It can be seen from Table 5 that in the UAs located in North East Wales such as Flintshire, Conwy and

\footnotetext{
${ }^{11}$ Giggs and Pattie (1992) discuss this issue in far greater detail, using data from the 1981 Census.
} 
Denbighshire, the Welsh born only just out-number those born outside the country. All of these UAs are close to the English border, and around 40 per cent of the population in each of these areas were born in England. Similar percentages are found in Powys and Monmouthshire, which again border England. However, there is a much lower percentage of immigrants in other UAs in South East Wales such as Newport, Torfaen and Blaenau Gwent. Furthermore, some UAs in the far west of Wales, Ceredigion in particular, also have a relatively high percentage of immigrants. Again the majority of those born outside Wales came from England. The cumulative effect of the low migration rates from the South Wales Valleys can be seen by the fact that in these areas between 85 and 92 per cent of the population were born in Wales, which is much higher than the national average. Thus the areas where the proportions born in Wales are lowest are mainly rural areas. Only a small percentage of the population in each of the Welsh UAs were born outside England and Wales, with Cardiff the only part of Wales where more than 5 per cent of its population originates from outside the EU.

The statistical relationship between local labour market conditions and migration is tested in Tables 6 and 7. Table 6 reports correlations coefficients and p-values between labour market indicators and in and out-migration rates for the 22 Welsh UAs. It can be seen that areas with high unemployment and sickness rates i.e. the South Wales Valleys have the lowest in and out-migration rates as well as the highest proportions born in Wales, whereas areas with the highest earnings have high rates of in and out migration and non-Welsh populations. These relationships can be further examined at a more disaggregated level using ward data. ${ }^{12}$ At this level, the

\footnotetext{
${ }^{12}$ Wards are the more disaggregated geographical area for which labour market statistics are released in the UK. There are 881 such areas in Wales.
} 
percentage of the area's population born outside Wales is used as the sole migration indicator. ${ }^{13}$ This seems reasonable since migration rates are highly correlated with the percentage of an area's non-Welsh population. In fact, Table 6 reports that the correlation between the two migration variables and the percentage of population born outside Wales at the UA level is at least 0.7 . Table 7 confirms that the relationships between labour market and migration variables observed in Table 6 are also present at the ward level. For example, areas with the lowest percentage of their population born outside Wales having by far the highest sickness and unemployment rates. There is also a positive and significant relationship between income levels and the percentage born outside Wales.

\section{Characteristics of migrants and potential migrants}

\subsection{Age}

In recent years, much debate has focused around the consequences of, and possible solutions, for an ageing population. Increased immigration is thought to be one way in which this problem can to some extent be ameliorated, at least in the short term, since immigrants are typically younger and have higher fertility rates (Zimmermann, 1995). Furthermore, Razin and Sadka (2000) show that immigration can be beneficial to all residents in an economy where pensions are paid on a pay-as-you-go basis. Kemnitz (2003) qualifies this finding when relaxing the assumption of competitive labour markets, showing that the low-skilled native population are harmed, but this effect is not large enough to outweigh the gains for other groups, resulting in an unambiguous gain for the population as a whole. In the current context, a net outflow of younger people from Wales to other parts of the UK will reduce the working population and increase the dependency ratio and a net inflow of older people into Wales can create

\footnotetext{
${ }^{13}$ Ward level information on in and out-migration was not available at the time of writing.
} 
pressure on particular social services. Therefore not only is the amount of migration important, but also the composition of migration flows, as this has implications for the age structure and hence the flexibility of local labour markets. Changes in the age structure of a labour market can have implications for employment, unemployment and activity rates as well as wage rates and the skills base. It also has implications for the ability of labour markets to respond to demand and supply shocks as older workers are seen as being less able to respond to change and are also less likely to migrate (Dixon, 2003).

Table 8 reports age-related migration inflows and outflows to and from each of the 22 Welsh UAs, as well as the net migration figure for each area. In terms of Wales as a whole, the only age group with a net out-migration is between the age group between 16 and $24 .^{14}$ To some extent this may be due to a relatively large number of Welsh students attending English universities. Overall, however, there was a net in-migration of around 7000 individuals in the year 1999-2000, with the 45-64 year age group accounting for more than half of the net inflow. It is mainly the rural UAs such as Conwy, Carmarthenshire, Powys and Pembrokeshire that have the highest amounts of net in-migration for this age group.

The Sample of Anonymised Records (SARs), which is a detailed sample (2 per cent) of micro data taken from the 1991 Census, can be used to compare the characteristics of migrants into Wales with those who have moved out, as well as with migrants moving

\footnotetext{
14 The only UAs which had a net in-migration of 16-24 year olds in 1999-2000 were Cardiff, Ceredigion, Gwynedd and Swansea and these areas contain the largest constituent parts of the University of Wales (Cardiff, Aberystwyth, Bangor and Swansea).
} 
within Wales and those individuals who have not moved at all. ${ }^{15}$ Thus we are able to compare the characteristics of four migrant groups as well as one non-migrant group. Using the SARs data, Table 9 also shows that there was a small net inflow of people into Wales from the rest of the UK. As expected, around two-thirds of individuals moving to Wales from other parts of the UK were born in England. Interestingly, the Welsh born accounted for 23 per cent and 30 per cent of individuals moving to Wales from other parts of the UK and from outside the UK respectively.

It can be seen using the $S A R S$ that non-migrants were considerably older than each of the migrant groups in 1990-91. The biggest differences occur in the 16-30 age category, which constitutes over 36 per cent of each of the migrant groups, compared to only 16 per cent of the non-migrant group. The percentages in the over 50 age category are more or less reversed for migrant and non-migrant groups. Amongst the migrant groups, those moving to Wales from outside the UK were on average the youngest, followed by out-migrants from Wales to other parts of the UK, migrants within Wales and in-migrants from other parts of the UK. When just individuals of working age are considered the pattern changes somewhat, with the average age of migrants moving from Wales to the rest of the UK now being the lowest of all the migrant groups. Therefore the age of individuals leaving Wales is below that of those entering the country. ${ }^{16}$

\footnotetext{
${ }^{15}$ The 1991 SARs are used since sample sizes in the LFS are too small to analyse Welsh migration because questions on migration are only asked in the Spring quarter each year and the 2001 SARs has yet to be released by the $O N S$.

${ }^{16}$ To our knowledge, no information is available on the characteristics of Welsh migrants living outside the UK.
} 


\subsection{Human Capital}

The skill composition of migration is also of vital importance for the future performance of both the sending and receiving economies. Within the receiving country, economic growth can be driven by the accumulation of human capital (Lucas, 1988). On the other hand, the outflow of human capital (i.e. a brain drain) has traditionally been thought to have a detrimental effect on labour exporting countries (Bhagwati and Hamada, 1974). However, more recent studies discuss certain situations where a brain drain can actually confer benefits on the sending country (Beine et al., 2001; Commander et al., 2002).

Table 10 presents information on educational differences between migrant groups by reporting the percentage of individuals of working age (excluding those who are currently students) in each of the migrant groups who possessed higher qualifications in 1990-91. It can be seen that the educational profile of non-migrants and those moving within Wales was fairly similar. In contrast, those individuals who moved from Wales to other parts of the UK were the most qualified, followed by those who moved to Wales from other parts of the UK and from outside the UK. These figures suggest, using a single cross section of data, that there has been a net brain drain from Wales.

To gain a more complete indication as to what extent a net brain drain has occurred over time, the most recent Labour Force Survey (LFS) data are examined. ${ }^{17}$ Table 11 contains information from the $L F S$ for 2003 and reports the cumulative impact of the migration of the highly educated from Wales as it reports educational attainment by country of birth and residence for the population of working age. Most notably, it can

\footnotetext{
${ }^{17}$ Information on country of birth within the UK only began to be collected in the LFS from 2001.
} 
be seen that around a third of the Welsh born living in other parts of the UK have degrees, compared to around only a tenth of the Welsh born still residing in the country of their birth. ${ }^{18}$ Although Wales also attracts highly qualified migrants since 22 per cent of immigrants to Wales have a degree, this is not enough to compensate for the migration of the well qualified Welsh born. These differences also seem to be widening given that in 1991, the SARs indicates that 20 per cent of the Welsh born living in other parts of Great Britain were graduates compared to 12 per cent of the non-Welsh born living in Wales. The percentage of Welsh born living elsewhere in the UK with no qualifications is also 4 percentage points lower than corresponding percentage of the non-Welsh born living in Wales. Interestingly, by way of comparison, only 27 per cent of Scots living elsewhere in the UK have degrees, whilst 30 per cent of non-Scots living in Scotland are graduates.

Migration may only be part of the story though as well educated Welsh born people living just over the English border may commute to work in Wales, or vice-versa. For example, Hunt (2000) analyses commuting as well as migration to obtain a more complete picture of the extent of the brain drain from East to West Germany. She finds that commuters are less skilled than migrants, possibly because the costs of moving deters the less skilled from migrating. However, the information reported in Table 11 suggests that commuting does not alter the situation that much since although a relatively high proportion of commuters to Wales have degrees and very few have no qualifications, far greater numbers live in Wales but work elsewhere in the UK. This additional outflow of well qualified Welsh residents is a further cause for concern.

\footnotetext{
${ }^{18}$ See also ONS (2004).
} 
The social class (occupational) data on migrant groups mirrors the findings regarding higher qualifications in that non-movers and internal migrants within Wales were comprised of a much lower percentage of professional and managerial individuals than those who moved longer distances. The highest proportion of professional/managerial individuals could be found amongst immigrants to Wales from outside the UK. However, the percentage of migrants leaving Wales from the professional/managerial and skilled classes was again higher than the equivalent percentages for migrants to Wales from other parts of the UK. Therefore using this single cross section, the social class data confirms the notion that there has been a net brain drain from Wales.

\subsection{Econometric estimates of migrant status}

The previous analysis has provided details on a number of aspects of Welsh migration using a range of data sets and descriptive statistics. Therefore in order the control for the influence of other covariates, it is necessary to estimate an econometric model to isolate some of the differences discussed previously. In particular, Table 12 reports multinomial logit estimates for the propensity to be in each of the migrant groups for non-students aged between 18 and $55 .^{19}$

Of most interest, it is found that migration decreases with age and is lower for those individuals with no higher qualifications. Both of these findings can be explained within a human capital framework. Younger people are more likely to migrate

\footnotetext{
${ }^{19} 55$ was chosen as the upper age limit because it is expected that individuals older than this are far less likely to move for job related reasons. Böheim and Taylor (2002) constrain their analysis of actual migration decisions to individuals aged between 16 and 55. 18 has been chosen as the lower limit so that the results can be compared directly with subsequent analysis.
} 
because they have a longer period over which they can pay back any moving costs they may incur, they are also less likely to have acquired location specific human capital and should have a lower psychological attachment with the area that they current reside than older individuals. Finally, more qualified individuals should be faced with a larger range of job opportunities, suffer lower psychic costs because they are already to have already left the family home and be better able to cover the financial costs of a move. Union wage bargaining and minimum wage rates should also reduce wage differentials amongst occupations that do not require higher qualifications.

Relative to the base category, which relates to those individuals who have moved from Wales to other parts of the country, individuals in all other migrant groups are older and have less higher qualifications. This is particularly true of non-migrants and those migrants who have not left Wales. In fact, the only significant differences between in and out-migrants to Wales are age and higher qualifications. Thus, using this particular cross section, it is clear that Wales loses a disproportionate share of its younger and more educated people, even after controlling for other personal characteristics, which is also consistent with the more recent evidence presented in Table 11.

In terms of other characteristics, marital status does not have a very important influence on migration, although those who are currently or have previously been married are slightly more likely to be non-movers. Non-movers and intra-regional migrants are also more likely to have dependant children. This is also consistent with the human capital model as partners and children are thought to tie an individual to their current area of residence, thereby increasing the cost of moving. Gender does not 
have that strong an effect on migrant status. The unemployed are significantly less likely to be non-movers compared to those in employment. Ethnic minorities are less likely to be non-movers and more likely to migrate to Wales from abroad, although it should be noted that Wales only has a small non-white population.

\subsection{Estimating the Willingness to Move}

Not only is it important to investigate the characteristics of individuals who actually move in a given period but also which type of individuals are likely to move, especially over long distances. This can be done using the 1995 British Social Attitudes Survey (BSAS) since this survey includes a question on an individual's Willingness to Move (WTM) from their current location. The $B S A S$ is an annual representative sample of adults aged 18 and over living in private households in Great Britain and contains details on a range of personal and area characteristics. ${ }^{20}$ However, only around a third of the BSAS respondents were asked the WTM questions. $^{21}$ Furthermore, as in Table 12, we constrain our data to include those individuals aged between 18 and 55. This reduces the useable sample to less than 700 individuals, of which under 50 are resident in Wales. Therefore we are unable to examine the Welsh responses to WTM questions separately but instead must analyse them in conjunction with the rest of the British sample.

Table 13 contains details of the sample respondents' stated WTM from their current area of residence. This information is collected over a number of different levels since respondents were asked how willing they would be to move away from their

\footnotetext{
${ }^{20}$ The achieved sample size in 1995 was 3633.

${ }^{21}$ Each individual who was identified to take part in the survey was allocated to the A, B or C third of the sample. Only those individuals allocated to the A version of the questionnaire were required to answer the questions on national identity and migration (Lilley et al., 1997).
} 
neighbourhood, town/city, county, Britain and Europe if they could improve their living or working conditions. ${ }^{22}$ Responses were given on a five-point scale, which was recoded so that a higher value indicates a greater WTM.

Focusing on the averages for all respondents, it can be seen that an individual's WTM decreases as the distance of the prospective move gets larger. This is exactly what the human capital model (Sjaastad, 1962) would predict since migration over longer distances is much less attractive due to the increased financial and indirect costs of longer moves (Schwartz, 1973). The indirect or 'psychic' costs are caused by the separation from friends, family and familiar surroundings and may be very high for certain individuals. Search costs will also increase with distance.

Given that the $B S A S$ also collects information on a range of personal characteristics this implies that the average WTM can be calculated for a range of demographic subgroups. The table reports the average WTM split by different personal characteristics: gender, sex, economic position, area of residence and education, as well as those characteristics which previous studies on the WTM/movement intentions focus upon e.g. unemployment (Ahn et al., 1999; Faini et al., 1997) and housing tenure (Hughes and McCormick, 1985). The table also reports p-values, to indicate whether the WTM differences between two sub-groups are statistically significantly.

It can be seen from Table 13 that males exhibit a higher WTM than females over all distances, although these differences are only significant for moves to another town/city or county and at the national level. This may suggest that males should be

\footnotetext{
${ }^{22}$ The precise wording of the questions from which this information is derived can be found in the Appendix.
} 
less tied to their area than females because of family considerations. In line with findings shown in Table 12, younger people are more willing to move than their elders and respondents with a higher education view moving a more attractive prospect than those who do not possess such qualifications. The differences between those with and without higher education become larger as the distance of the prospective move increases. In common with higher education graduates, nonmanuals display a far higher WTM outside of their counties than those with manual occupations. A possible explanation for this finding is that professionals and managers are more likely than other occupations to operate within national rather than local labour markets.

Unemployed individuals appear more willing to move than those with jobs or inactive people, although the differences between the employed and unemployed are fairly small. In contrast, individuals who are currently inactive appear to be very reluctant to move far from their current location. In terms of housing tenure, private renters are the most willing to move, providing some support for the conjecture of Oswald (1996) that the lack of private rented accommodation impedes labour mobility. Furthermore, in line with the arguments of Hughes and McCormick (1981, 1985), there appears to be a reluctance on the part of social housing tenants to engage in long distance migration.

It might also have been thought that individuals living the north of England, Wales and Scotland would display a higher WTM than their southern counterparts. However, this pattern is not observed in the raw data, with the only significant differences found between Wales and the North of England for the WTM longer distances. The Welsh appear to be relatively reluctant to move from their neighbourhood - they have the 
lowest average WTM of all four areas at this level - but relatively willing to move longer distances, especially overseas. It should be noted though that the sample sizes for Wales and Scotland are fairly small.

Econometric models of an individual's movement intentions or their willingness to move have been estimated by several authors, including Ahn et al. (1999) for Spain, Burda et al. (1998) for Germany, Faini et al. (1997) for Italy, Yang (2000) for China and Hughes and McCormick (1985) and Gordon and Molho (1995) for Great Britain. Econometric models have been estimated since there is strong evidence to suggest that individuals who have a more favourable attitude towards migration are more likely to move. For example, Böheim and Taylor (2002) examine longitudinal data from the British Household Panel Survey and find that the actual propensity for moving was around three times higher for respondents who had expressed a preference for moving than those who did not express a preference for moving in the previous wave. Gordon and Molho (1995) also report evidence from a survey of actual and potential British migrants in 1980 that at least 90 per cent of the potential migrants moved within five years, of whom around a half moved within a year.

Most of the studies cited above estimate dichotomous dependent variable (i.e. logit or probit) models, but given the categorical and ordered nature of the WTM variable, ordered probit models are estimated. Estimates are reported in Table 14 for an individual's WTM to another location within Britain at the five levels reported in Table 13 i.e. neighbourhood, town/city, county, country and continent. By examining both the estimates for the WTM country and continent, this should provide an indication of the factors that are important in determining the WTM over longer distances, which is useful since no question was asked on the WTM region. Two 
specifications are reported for each distance of prospective move, one which does not include any interaction terms and another which does.

Focusing initially on specification 1, it is found for each of the models that females are less willing to move any distance from their current place of residence after controlling for other influences, although the gender difference is only significant at the 5 per cent level for moving to a different town/city or county. Age has a negative impact on an individual's WTM and this effect is significant at the 5 per cent level apart from the WTM town/city. This is consistent with the findings of other empirical studies of the determinants of individual migration decisions, which have typically found that younger individuals have far higher migration rates (Molho, 1987; Pissarides and Wadsworth, 1989; Thomas, 1994; Boheim and Taylor, 2002).

The higher education dummy is not significant for prospective moves away from the individual's neighbourhood or town. However, the coefficient on the dummy does increase as the distance of the prospective move increases and educational differences are significant for prospective moves to another county, country and continent. This indicates that those with qualifications are far more prepared to move long distances. In accordance with the raw figures reported in Table 13, unemployed people are more willing to move from their neighbourhood than employed people but less willing to move longer distances, although none of these influences are significant. On the other hand, inactive people are far less willing to move long distances, even after controlling for other personal characteristics.

Marital status does not exert a very important influence, although widows, divorcees and separated individuals do appear to have a higher WTM than those who are 
married. However, there are no great differences between married and single people and the coefficient on the dummy variable for singles is negative in some of the models. This is again slightly surprising given that married individuals will usually have stronger ties to their area. Pissarides and Wadsworth (1989) and Boheim and Taylor (2002) find that marital status is important in determining whether or not an individual moves, with single persons having the highest migration probability. Mincer (1978) focuses on the family migration decision and argues that migration rates would be much higher if people were just concerned about their own circumstances, rather than taking into account those of others. Similarly, one would expect larger households (who will have more children) to be less willing to move their families. This coefficient attached to this variable is negative in each of the models but is only significant at the 5 per cent level in the WTM country and continent models. Ethnicity is not a significant determinant of the WTM in any of the models.

The country of residence dummies are not significant apart for prospective moves over longer distances. As was the case with the raw figures, it can be seen from Table 14 that inhabitants of Wales were slightly less willing to move from their neighbourhoods in 1995 than people living in England but the relative WTM of Welsh people increases as the distance of the prospective move beomes bigger. In particular, Welsh residents were significantly more willing to move abroad than either people from Northern England or Scotland.

Turning our attention to the models that estimate specification 2, which include the interaction terms, it can be seen that the interaction between age and the Wales dummy is negative and significant in each of the models. This indicates that young 
people in Wales are more willing to move than comparable youngsters in other parts of Britain. The interaction between the higher education and Wales dummies is positive in each model, but is only significant at the 5 per cent level for prospective moves from the individual's own neighbourhood and town/city. ${ }^{23}$ However, as mentioned previously, those with a higher education are far more willing to move longer distances. Thus, not only are well qualified Welsh youngsters prepared to move long distances, they also appear to be more prepared to move shorter distances than their counterparts form other parts of Britain.

\section{Concluding Comments}

Competitive theory suggests that spatial real wage and unemployment differentials should disappear as a result of the migration of labour and capital and so government intervention is unnecessary. Furthermore, the role of migration in reducing local and regional inequalities is likely to be more important now as a consequence of the reduction in regional assistance to deprived areas in the UK in recent decades, the prospect of reduced EU funding post-enlargement and the continued reluctance of firms to relocate. However, evidence presented in this paper suggests that this process, if working at all, is working very slowly. Indeed, alternative theories have been developed which emphasize virtuous and vicious circles of development rather than convergence to equilibrium. Given that labour mobility tends to be highest amongst the young and better skilled in Wales, migration is likely to lead to divergent development. This issue is of particular concern to areas such as the South Wales Valleys. It is also found that large income differences exist not only at the local level but which also appear to be widening at the regional level in the UK, with London and the South East pulling away from the national average. Given that further European

\footnotetext{
${ }^{23}$ This interaction is also significant at the 10 per cent level in the WTM county model.
} 
integration is expected over the coming years, in particular if the UK becomes part of the European Monetary Union, these differentials are likely to widen yet further, with the prospects of the more deprived Welsh areas likely to further worsen without regional assistance.

The paper reports that there has been a net out-migration of younger people from Wales, which can have a negative impact on the national as well as the local economy, especially if the area mainly attracts retired people. The net out-migration of younger individuals and net inflow of older and retired individuals, which results in a general ageing of the workforce, can have dramatic implications for the dynamism of local labour markets. Whilst older workers are less likely to become unemployed once employed, they generally experience longer spells of unemployment and a greater tendency to become inactive than younger workers. They are also less likely to take part in formal education and workplace training. After the age of 25, relatively few individuals gain additional formal qualifications (Dixon, 2003). This can have implications for the flexibility of a local labour market and its attractiveness as a place to invest as these areas will be less able to respond appropriately to demand shocks and technological change as they become more dependant on older workers to meet developing skill needs (OECD, 1998).

Another of the main findings is that educated people actually move and are far more willing to move long distances. This can partly be explained by those with higher qualifications facing lower psychic costs as they have been to university or met people from different backgrounds and so have already cut some of their ties with their local communities. However, although education is conducive to producing a more mobile labour force, Wales has lost a disproportionate share of its highly qualified human 
capital. Furthermore, highly educated young people living in Wales also appear to have a greater willingness to move long distances. This suggests that although the Welsh economy has been successful in the recent past in creating new jobs, greater attempts should be made to create high-value jobs and to implement development strategies which distribute such jobs across the country in order to retain and attract talented workers.

The evidence also suggests a need for increased migration among certain groups e.g. those with manual occupations and people from particular areas, especially the South Wales Valleys, since it is found that the most deprived parts of Wales have the lowest migration rates. This applies as much to in-migration as it does to out-migration since not only will this improve the fluidity of the Welsh labour market but also provides an injection of human capital into the Valleys. As well as educational initiatives in more deprived areas, reform of the housing sector could help to remove some of the impediments to mobility because of the important links that exist between housing and labour markets (Henley, 1998). For example, the movement of labour is restricted for social housing tenants by administrative restrictions on moving between local authorities, and for owner occupiers by high house prices, pre-contract uncertainties and the transactions costs that are associated with moving house. Improvements in job prospects, housing and local amenities would also encourage more people into the deprived areas. Whilst changes in the benefit system such as regularly assessing entitlement to invalidity benefits could also encourage migration away from areas where sickness rates are currently extremely high. 


\section{References}

Ahn, N., De la Rica, S. and Ugidos, A. (1999), "Willingness to move for work and unemployment duration in Spain", Economica, 66, 335-57.

Armstrong, H. and Taylor, J. (2000), Regional Economics and Policy, $3^{\text {rd }}$ Edition, Blackwell, Oxford.

Barro, R. and Sala-i-Martin, X. (1991), "Convergence across states and regions", Brookings Papers on Economic Activity, No. 1, 107-82.

Beine, M., Docquier, F. and Rapoport, H. (2001), "Brain drain and economic growth: Theory and evidence", Journal of Development Economics, 64, 275-89.

Bhagwati, J. N. and Hamada, K. (1974), "The brain drain, international integration of markets for professionals and unemployment", Journal of Development Economics, 1, $19-42$.

Blackaby, D. H. and Manning, D. N. (1990), "The north-south divide: Questions of existence and stability”, Economic Journal, 100, 510-27.

Blackaby, D. H. and Murphy, P. D. (1995), "Earnings, unemployment and Britain's north-south divide: Real or imaginary?", Oxford Bulletin of Economics and Statistics, 57, 487-512.

Blanchard, O. J. and Katz, L. F. (1992), "Regional evolutions", Brookings Papers on Economic Activity, No. 1., 1-75.

Boheim, R. and Taylor, M. (2002), "Tied down or room to move? Investigating the relationships between housing tenure, employment status and residential mobility in Britain", Scottish Journal of Political Economy, 49, 369-92.

Borjas, G. J. (1994), "The economics of immigration", Journal of Economic Literature, 32, 1667-1717.

Borjas, G. J. (1999), "The economic analysis of immigration" in O. Ashenfelter and D. Card (eds), Handbook of Labor Economics, Volume 3A, Elsevier, Amsterdam.

Borjas, G. J. (2001), "Does immigration grease the wheels of the labor market?", Brookings Papers on Economic Activity, No. 1, 69-133.

Burda, M. C., Härdle, W., Muller, M. and Werwatz, A. (1998), "Semiparametric analysis of German East-West migration intentions: Facts and theory", Journal of Applied Econometrics, 13, 525-41.

Cameron, G. and Muellbauer, J. (2000), "Earnings biases in the United Kingdom regional accounts: Some economic policy and research implications", Economic Journal, 110, F412-29.

Commander, S., Kangasniem, M. and Winters, L. A. (2002), "The brain drain: Curse or boon? A survey of the literature", Paper presented at the CEPR/NBER/SNS Seminar on International Trade, Stockholm, May 24-25. 
Daniel, G. H. (1940), "Some factors affecting the movement of labour", Oxford Economic Papers, 3, 144-79.

Decressin, J. and Fatás, A. (1995), "Regional labour market dynamics in Europe", European Economic Review, 39, 1627-55.

Drinkwater, S. (2003), "Estimating the willingness to move within Great Britain", Importance and Implications, WELMERC Discussion Paper 2003-06, University of Wales Swansea.

Faini, R., Galli, G., Gennari, P. and Rossi, F. (1997), “An empirical puzzle: Falling migration and growing unemployment differentials among Italian regions", European Economic Review, 41, 571-9.

Fothergill, S. (2001), "The true scale of the regional problem in the UK", Regional Studies, 35, 241-6.

Giggs, J. and Pattie, C. (1992), "Wales as a plural society", 5, Contemporary Wales, 25-64.

Gordon, I. R. and Molho, I. (1995), "Duration dependence in migration behaviour: Cumulative inertia versus stochastic change", Environment and Planning A, 27, 196175.

Gordon, I. R. and Molho, I. (1998), "A multi-stream analysis of the changing pattern of interregional migration in Great Britain, 1960-81", Regional Studies, 32, 309-23.

Greenwood, M. J. (1997), "Internal migration in developed countries", in M. R. Rosenzweig and O. Stark (eds), Handbook of Population and Family Economics, Volume 1B, Elsevir, Amsterdam.

Henley, A. (1998), "Residential mobility, housing equity and the labour market", Economic Journal, 108, 414-27.

Hughes, G. A. and McCormick, B. (1981), "Do council housing policies reduce migration between regions?", Economic Journal, 91, 919-37.

Hughes, G. A. and McCormick, B. (1985), "Migration intentions in the UK: Which households want to migrate and which succeed?", Economic Journal, 95, 113-23.

Hughes, G. A. and McCormick, B. (1994), "Did migration in the 1980s narrow the north-south divide?", Economica, 61, 509-27.

Hunt, J. (2000), “Why do people still live in East Germany?", IZA Discussion Paper No. 123.

Kemnitz, A. (2003), "Immigration, unemployment and pensions", Scandinavian Journal of Economics, 105, 31-47

Dixon, S. (2003), "Implications of population ageing for the labour market", Labour Market Trends, 111(2), 67-76. 
Lilley, S. J., Brook, L., Park, A. and Thomson, K. (1997), British Social Attitudes 1995 Survey: Technical Report, Social and Community Planning Research, London.

Linacre, A. (2002), "Regional, sub-regional and local area household income", Economic Trends, May, No. 582, 81-112.

Lucas, R. E. (1988), "On the mechanics of economic development", Journal of Monetary Economics, 22(1), 3-42.

Martin, R. (1997), "Regional unemployment disparities and their dynamics", Regional Studies, 31, 237-52.

McCormick, B. (1997), "Regional unemployment and labour mobility in the UK", European Economic Review, 41, 581-9.

Mincer, J. (1978), "Family migration decisions", Journal of Political Economy, 86, 749-73.

Molho, I. (1987), "The migration decisions of young men in Great Britain", Applied Economics, 19, 221-43.

Möller, J. (2001), "Regional adjustment dynamics", HWWA Discussion Paper No. 146, Hamburg.

OECD (1998), "Workforce ageing", in OECD Employment Outlook 1998, Organisation for Economic Cooperation and Development, Paris, 123-51.

ONS (2004), Focus on Wales, Office for National Statistics, London.

Oswald, A. (1996), "A conjecture on the explanation for high unemployment in the industrialised nations”, The Warwick Economics Research Papers Series No. 475.

Pissarides, C. and McMaster, I. (1990), "Regional migration, wages and unemployment: Empirical evidence and implications for policy", Oxford Economic Papers, 42, 812-31.

Pissarides, C. and Wadsworth, J. (1989), "Unemployment and the inter-regional mobility of labour", Economic Journal, 99, 739-55.

Razin, A. and Sadka, E. (2000), "Unskilled migration: a burden or a boon for the welfare state?", Scandinavian Journal of Economics, 102, 463-80.

Schwartz, A. (1973), "Interpreting the effect of distance on migration", Journal of Political Economy, 81, 1153-69.

Scott, P. (2004), "Regional development and policy since 1945", in R. Floud, and P. Johnson (eds), The Cambridge Economic History of Britain, Volume 3, Cambridge University Press, Cambridge.

Sjaastad, L. (1962), “The costs and returns of human migration", Journal of Political Economy, 70, 80-93. 
Thomas, A. (1993), "The influence of wages and house prices on British interregional migration decisions", Applied Economics, 25, 1261-8.

Thomas, B. (1930), "The migration of labour into the Glamorganshire coalfield (1861-1911), Economica, 30, 275-94.

Webster, D. (2000), "The geographical concentration of labour-market disadvantage", Oxford Review of Economic Policy, 16(1), 114-28.

Wren, C. (1996), "Grant equivalent expenditure on industrial subsidies in the post-war United Kingdom”, Oxford Bulletin of Economics and Statistics, 58, 317-53.

Yang, X. (2000), "Determinants of migration intentions in Hubei province, China: Individual versus family migration", Environment and Planning A, 32, 769-87.

Zimmermann, K. F. (1995), "The European Migration Problem", Journal of Economic Perspectives, 9(2), 45-62. 


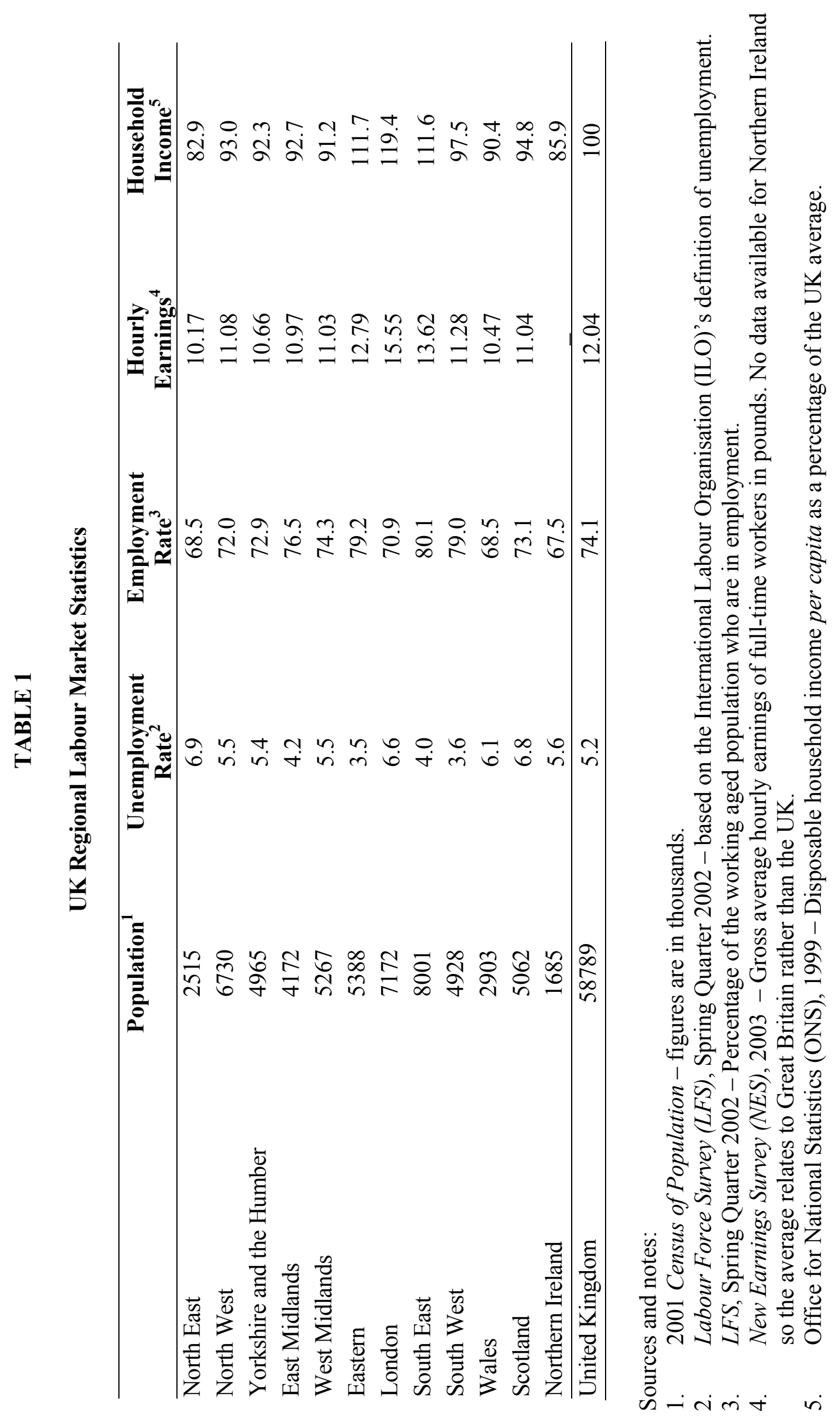




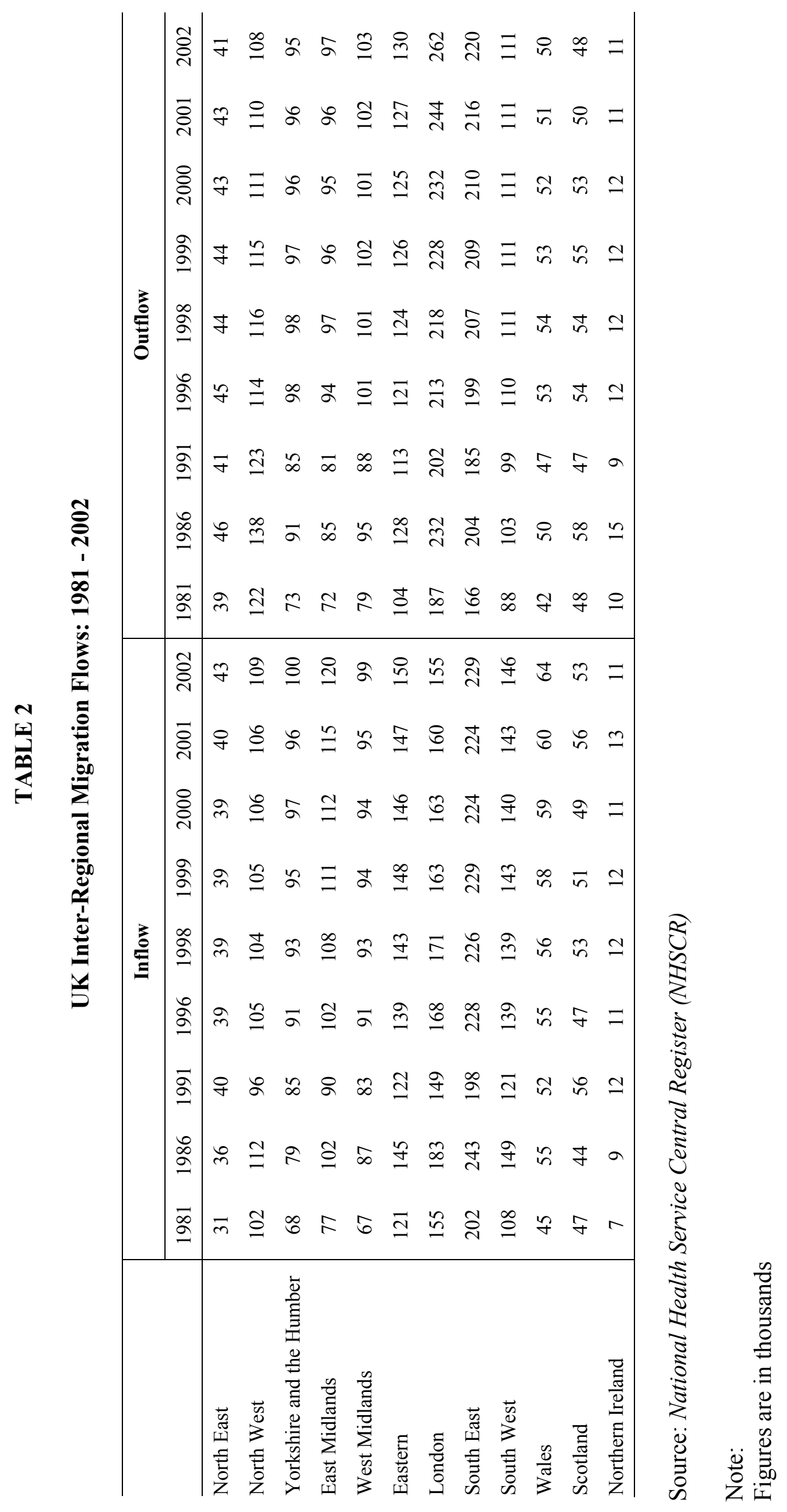


TABLE 3

Labour Market Indicators for Welsh Unitary Authorities

\begin{tabular}{|c|c|c|c|c|}
\hline & $\begin{array}{c}\text { Unemployment } \\
\text { Rate }^{1} \\
\end{array}$ & $\begin{array}{c}\text { Employment } \\
\text { Rate }^{2} \\
\end{array}$ & $\begin{array}{c}\text { Hourly } \\
\text { Earnings }\end{array}$ & $\begin{array}{c}\text { Sickness } \\
\text { Rate }^{4} \\
\end{array}$ \\
\hline Blaenau Gwent $^{5}$ & 8.4 & 54.3 & 8.77 & 13.8 \\
\hline Bridgend & 5.7 & 74.9 & 10.53 & 10.7 \\
\hline Caerphilly & 6.0 & 68.2 & 9.92 & 12.1 \\
\hline Cardiff & 4.9 & 72.8 & 11.35 & 6.6 \\
\hline Carmarthenshire & 5.7 & 65.3 & 9.64 & 11.1 \\
\hline Ceredigion & 5.0 & 62.4 & 10.56 & 6.9 \\
\hline Conwy & 6.1 & 74.4 & 10.71 & 7.9 \\
\hline Denbighshire & 5.5 & 72.6 & 10.74 & 8.6 \\
\hline Flintshire & 4.4 & 73.6 & 10.84 & 6.5 \\
\hline Gwynedd & 6.8 & 72.4 & 9.38 & 6.9 \\
\hline Isle of Anglesey & 7.9 & 63.0 & 9.81 & 8.4 \\
\hline Merthyr Tydfil & 7.4 & 54.6 & 9.62 & 15.9 \\
\hline Monmouthshire & 4.0 & 76.8 & 12.55 & 5.8 \\
\hline Neath Port Talbot & 7.0 & 56.6 & 10.49 & 13.6 \\
\hline Newport & 6.2 & 77.7 & 10.85 & 7.9 \\
\hline Pembrokeshire & 6.5 & 68.8 & 9.98 & 8.2 \\
\hline Powys & 4.0 & 79.0 & 10.77 & 6.2 \\
\hline Rhondda;Cynon;Taff & 6.2 & 63.9 & 9.69 & 13.0 \\
\hline Swansea & 6.2 & 70.6 & 10.06 & 9.8 \\
\hline Torfaen & 5.0 & 69.2 & 10.23 & 6.4 \\
\hline Vale of Glamorgan & 5.6 & 69.4 & 12.32 & 10.2 \\
\hline Wrexham & 5.1 & 74.3 & 10.19 & 8.0 \\
\hline WALES & 5.7 & 69.6 & 10.47 & 9.2 \\
\hline UNITED KINGDOM & 5.0 & 74.1 & 12.04 & 5.5 \\
\hline
\end{tabular}

Sources and notes:

1. 2001 Census of Population - this measure of unemployment is based on responses to a question which asked the economic activity of the individual the week before the Census. This is compatible with the ILO's definition of economic status. The denominator is the economically active population (including economically active students). The resultant unemployment rate is very similar to that from the ILO definition (the UK rate was $4.9 \%$ and the Welsh rate 5.8\% in Spring 2001), without suffering from the small samples that affect the accuracy of sub-regional statistics using the LFS.

2. LFS, March 2000-February 2001 - Percentage of the working aged population who are in employment.

3. NES, 2003 - Gross average hourly earnings of full-time workers in pounds. Figure for UK relates to Great Britain.

4. 2001 Census of Population - Percentage of population aged 16 and over described as permanently sick. Figure for UK relates to England and Wales.

5. Valley UAs in bold. 
TABLE 4

Migration Statistics for Welsh Unitary Authorities and England: April 2001

\begin{tabular}{|c|c|c|c|c|c|c|c|}
\hline & Pop. & $\begin{array}{c}\text { \% who } \\
\text { are } \\
\text { migrants }\end{array}$ & $\begin{array}{c}\% \\
\text { moving } \\
\text { within } \\
\text { the } \\
\text { area }\end{array}$ & $\begin{array}{c}\% \\
\text { moving } \\
\text { in from } \\
\text { elsewhere } \\
\text { in the } \\
\text { UK }\end{array}$ & $\begin{array}{c}\% \\
\text { moving } \\
\text { in from } \\
\text { outside } \\
\text { the } \mathbf{U K}^{1}\end{array}$ & $\begin{array}{c}\% \text { with } \\
\text { no } \\
\text { previous } \\
\text { address }\end{array}$ & $\begin{array}{c}\text { \% } \\
\text { moving } \\
\text { out to } \\
\text { elsewhere } \\
\text { in the } \\
\text { UK }\end{array}$ \\
\hline Blaenau Gwent $^{3}$ & 70,064 & 9.05 & 6.88 & 1.40 & 0.06 & 0.71 & 1.79 \\
\hline Bridgend & 128,645 & 9.97 & 6.70 & 2.41 & 0.22 & 0.65 & 2.44 \\
\hline Caerphilly & 169,519 & 9.42 & 6.57 & 2.09 & 0.10 & 0.65 & 2.05 \\
\hline Cardiff & 305,353 & 15.59 & 9.20 & 4.54 & 0.88 & 0.96 & 4.26 \\
\hline Carmarthenshire & 172,842 & 10.50 & 6.56 & 3.00 & 0.24 & 0.70 & 2.52 \\
\hline Ceredigion & 74,941 & 18.04 & 10.08 & 6.54 & 0.64 & 0.78 & 5.39 \\
\hline Conwy & 109,596 & 11.71 & 6.91 & 3.84 & 0.27 & 0.69 & 3.17 \\
\hline Denbighshire & 93,065 & 11.27 & 6.39 & 3.93 & 0.29 & 0.66 & 3.51 \\
\hline Flintshire & 148,594 & 9.47 & 5.64 & 3.11 & 0.22 & 0.50 & 3.06 \\
\hline Gwynedd & 116,843 & 12.02 & 7.34 & 3.66 & 0.33 & 0.69 & 3.46 \\
\hline Isle of Anglesey & 66,829 & 10.02 & 6.03 & 3.13 & 0.27 & 0.59 & 3.28 \\
\hline Merthyr Tydfil & 55,981 & 8.40 & 5.94 & 1.68 & 0.12 & 0.66 & 2.16 \\
\hline Monmouthshire & 84,885 & 10.75 & 5.14 & 4.77 & 0.25 & 0.58 & 4.01 \\
\hline Neath Port Talbot & 134,468 & 9.23 & 6.40 & 2.14 & 0.11 & 0.58 & 2.08 \\
\hline Newport & 137,011 & 10.41 & 6.39 & 2.97 & 0.27 & 0.79 & 2.67 \\
\hline Pembrokeshire & 114,131 & 12.03 & 7.68 & 3.30 & 0.34 & 0.72 & 2.96 \\
\hline Powys & 126,354 & 10.67 & 6.04 & 3.73 & 0.34 & 0.56 & 3.40 \\
\hline Rhondda;Cynon;Taff & 231,946 & 9.62 & 6.72 & 2.04 & 0.24 & 0.62 & 2.10 \\
\hline Swansea & 223,301 & 12.19 & 8.10 & 2.81 & 0.53 & 0.74 & 2.88 \\
\hline Torfaen & 90,949 & 8.48 & 5.96 & 1.83 & 0.08 & 0.61 & 2.16 \\
\hline Vale of Glamorgan & 119,292 & 11.21 & 6.57 & 3.60 & 0.49 & 0.54 & 3.64 \\
\hline Wrexham & 128,476 & 10.35 & 6.67 & 2.84 & 0.29 & 0.56 & 2.38 \\
\hline WALES & $2,903,085$ & 11.17 & 6.99 & 3.15 & 0.34 & 0.68 & 2.97 \\
\hline ENGLAND & $49,138,831$ & 12.24 & 10.49 & 0.20 & 0.73 & 0.81 & 0.21 \\
\hline
\end{tabular}

Source: Census of Population

Notes:

1. This category includes UK - part not specified and Ireland - part not specified, the Channel Islands and the Isle of Man.

2. ONS note that responses in the 'No usual address one year ago' category were higher than expected. They also note that care needs to be taken when analyzing the migration into England and Wales from outside the UK.

3. Valley UAs in bold. 
TABLE 5

Country of Birth of Residents in Welsh Unitary Authorities and Other Parts of the UK: April 2001

\begin{tabular}{|c|c|c|c|c|c|c|c|}
\hline & $\begin{array}{l}\% \text { born } \\
\text { in } \\
\text { England }\end{array}$ & $\begin{array}{l}\% \text { born } \\
\text { in } \\
\text { Scotland }\end{array}$ & $\begin{array}{c}\% \\
\text { born } \\
\text { in } \\
\text { Wales }\end{array}$ & $\begin{array}{l}\text { \% born } \\
\text { in } \\
\text { Northern } \\
\text { Ireland }\end{array}$ & $\begin{array}{c}\text { \% born } \\
\text { in } \\
\text { Republic } \\
\text { of } \\
\text { Ireland } \\
\end{array}$ & $\begin{array}{c}\text { \% born } \\
\text { in other } \\
\text { EU } \\
\text { Countries }\end{array}$ & $\begin{array}{l}\text { \% born } \\
\text { elsewhere }\end{array}$ \\
\hline Blaenau Gwent & 6.39 & 0.30 & 92.08 & 0.10 & 0.14 & $\mathbf{0 . 3 3}$ & 0.66 \\
\hline Bridgend & 11.78 & 0.82 & 84.69 & 0.26 & 0.33 & 0.62 & 1.50 \\
\hline Caerphilly & 7.75 & 0.51 & 89.94 & 0.18 & 0.19 & 0.49 & 0.93 \\
\hline Cardiff & 16.26 & 0.90 & 74.95 & 0.32 & 0.63 & 1.47 & 5.47 \\
\hline Carmarthenshire & 16.76 & 0.64 & 80.07 & 0.23 & 0.37 & 0.69 & 1.24 \\
\hline Ceredigion & 36.43 & 0.98 & 58.58 & 0.33 & 0.55 & 1.13 & 2.00 \\
\hline Conwy & 41.18 & 1.18 & 53.96 & 0.39 & 0.88 & 0.81 & 1.60 \\
\hline Denbighshire & 37.85 & 1.13 & 57.90 & 0.37 & 0.50 & 0.69 & 1.56 \\
\hline Flintshire & 44.71 & 1.23 & 51.14 & 0.36 & 0.47 & 0.87 & 1.22 \\
\hline Gwynedd & 26.55 & 0.67 & 69.81 & 0.26 & 0.44 & 0.72 & 1.55 \\
\hline Isle of Anglesey & 28.37 & 1.12 & 67.57 & 0.33 & 0.73 & 0.63 & 1.24 \\
\hline Merthyr Tydfil & 6.01 & 0.46 & 91.96 & 0.12 & 0.24 & 0.33 & 0.88 \\
\hline Monmouthshire & 33.80 & 1.36 & 61.30 & 0.34 & 0.40 & 0.92 & 1.88 \\
\hline Neath Port Talbot & 7.92 & 0.58 & 89.49 & 0.16 & 0.39 & 0.47 & 0.99 \\
\hline Newport & 13.43 & 0.79 & 81.12 & 0.26 & 0.59 & 0.90 & 2.91 \\
\hline Pembrokeshire & 26.33 & 1.21 & 68.72 & 0.35 & 0.67 & 1.09 & 1.62 \\
\hline Powys & 40.62 & 0.94 & 55.59 & 0.26 & 0.30 & 0.75 & 1.54 \\
\hline Rhondda;Cynon;Taff & 7.57 & 0.46 & 89.92 & 0.15 & 0.25 & 0.59 & 1.05 \\
\hline Swansea & 13.34 & 0.78 & 82.07 & 0.25 & 0.42 & 0.95 & 2.20 \\
\hline Torfaen & 11.51 & 0.72 & 85.53 & 0.27 & 0.40 & 0.54 & 1.03 \\
\hline Vale of Glamorgan & 18.97 & 1.29 & 75.66 & 0.39 & 0.41 & 1.07 & 2.22 \\
\hline Wrexham & 24.46 & 0.86 & 71.92 & 0.30 & 0.35 & 0.74 & 1.37 \\
\hline WALES & 20.32 & 0.84 & 75.39 & 0.27 & 0.44 & 0.82 & 1.92 \\
\hline ENGLAND & 87.44 & 1.62 & 1.24 & 0.44 & 0.94 & 1.41 & 6.91 \\
\hline NORTHERN IRELAND & 3.66 & 1.00 & 0.18 & 91.04 & 2.32 & 0.61 & 1.20 \\
\hline SCOTLAND & 8.08 & 87.13 & 0.33 & 0.66 & 0.43 & 0.88 & 2.50 \\
\hline
\end{tabular}

Source: Census of Population

Note:

Valley UAs in bold. 
TABLE 6

\section{Correlation Matrix Between Labour Market and Migration Variables for Welsh Unitary Authorities: 2001}

\begin{tabular}{|c|c|c|c|c|c|c|}
\hline & Earnings & $\begin{array}{l}\text { Unempl. } \\
\text { Rate }\end{array}$ & $\begin{array}{l}\text { Sickness } \\
\text { Rate }\end{array}$ & $\begin{array}{l}\text { In-mig. } \\
\text { Rate }\end{array}$ & $\begin{array}{l}\text { Out-mig. } \\
\text { Rate }\end{array}$ & $\begin{array}{l}\text { \% Non- } \\
\text { Welsh }\end{array}$ \\
\hline Earnings $^{1}$ & 1.000 & & & & & \\
\hline $\begin{array}{l}\text { Unemployment } \\
\text { Rate }\end{array}$ & $\begin{array}{c}-0.673 \\
(0.001)^{2}\end{array}$ & 1.000 & & & & \\
\hline Sickness Rate & $\begin{array}{l}-0.479 \\
(0.024)\end{array}$ & $\begin{array}{c}0.664 \\
(0.001)\end{array}$ & 1.000 & & & \\
\hline In-migration Rate $^{3}$ & $\begin{array}{c}0.544 \\
(0.009)\end{array}$ & $\begin{array}{l}-0.524 \\
(0.012)\end{array}$ & $\begin{array}{l}-0.549 \\
(0.008)\end{array}$ & 1.000 & & \\
\hline $\begin{array}{l}\text { Out-migration } \\
\text { Rate }^{4}\end{array}$ & $\begin{array}{c}0.549 \\
(0.008)\end{array}$ & $\begin{array}{l}-0.468 \\
(0.028)\end{array}$ & $\begin{array}{l}-0.650 \\
(0.001)\end{array}$ & $\begin{array}{c}0.971 \\
(0.000)\end{array}$ & 1.000 & \\
\hline$\%$ Non-Welsh & $\begin{array}{c}0.438 \\
(0.041)\end{array}$ & $\begin{array}{l}-0.538 \\
(0.021)\end{array}$ & $\begin{array}{l}-0.761 \\
(0.000)\end{array}$ & $\begin{array}{c}0.700 \\
(0.003)\end{array}$ & $\begin{array}{c}0.737 \\
(0.001)\end{array}$ & 1.000 \\
\hline $\mathrm{N}$ & 22 & 22 & 22 & 22 & 22 & 22 \\
\hline
\end{tabular}

Notes:

1. Residence based earnings data for 2003. For further details, see notes to Table 3.

2. $\mathrm{p}$-values for the correlation coefficients are in parentheses.

3. In-migration rate is the percentage moving to the UA from elsewhere in the UK

4. Out-migration rate is the percentage moving from the UA to elsewhere in the UK.

TABLE 7

Correlation Matrix between Labour Market and Migration Variables for Welsh Wards: 2001

\begin{tabular}{lcccc}
\hline & Income & $\begin{array}{c}\text { Unempl. } \\
\text { Rate }\end{array}$ & $\begin{array}{c}\text { Sickness } \\
\text { Rate }\end{array}$ & $\begin{array}{c}\text { \% Non- } \\
\text { Welsh }\end{array}$ \\
\hline Income $^{1}$ & 1.000 & & & \\
Unemployment Rate & -0.608 & & & \\
& $(0.000)^{2}$ & 1.000 & & \\
Sickness Rate & -0.614 & 0.649 & & \\
& $(0.000)$ & $(0.000)$ & 1.000 & \\
\% Non-Welsh & 0.315 & -0.331 & -0.633 & 1.000 \\
\hline $\mathrm{N}$ & $(0.000)$ & $(0.000)$ & $(0.000)$ & 881 \\
\hline
\end{tabular}

Notes:

1. Income data are based on ONS estimates produced for 1998. The sample size for income is lower because the ward boundaries are not exactly the same as those used in the 2001 Census, which meant that some wards could not be matched.

2. $\mathrm{p}$-values for the correlation coefficients are in parentheses. 


\section{TABLE 8}

Age Related Migration Statistics for Welsh Unitary Authorities: 1999-2000

\begin{tabular}{|c|c|c|c|c|c|c|c|c|c|c|c|c|c|c|c|c|c|}
\hline & \multicolumn{3}{|c|}{ Age 0-15 } & \multicolumn{3}{|c|}{ Age 16-24 } & \multicolumn{3}{|c|}{ Age 25-44 } & \multicolumn{2}{|c|}{ Age 45-64 } & \multicolumn{3}{|c|}{65 and over } & \multicolumn{3}{|c|}{ All ages } \\
\hline & & $\mathbf{O}^{2}$ & Net & I & $\mathbf{O}$ & Net & I & $\mathbf{O}$ & Net & I O & Net & I & $\mathbf{O}$ & Net & I & $\mathbf{O}$ & Net \\
\hline & 3 & 0.4 & -0.1 & 0.3 & 0.3 & -0.1 & 0.4 & 0.5 & & 0.20 .2 & 0.0 & 0.1 & 0.1 & 0.0 & 1.2 & 1.5 & -0.3 \\
\hline ridgend & 0.7 & 0.8 & -0.1 & 0.6 & 0.8 & -0.2 & 1.3 & 1.4 & -0.1 & 0.50 .5 & 0.1 & 0.4 & 0.3 & 0.0 & 3.5 & 3.9 & -0.3 \\
\hline aerphilly & .0 & 0.9 & 0.1 & 0.8 & 1.0 & -0.2 & .7 & 1.5 & 0.2 & 0.50 .5 & 0.0 & 0.2 & 0.2 & 0.0 & 4.2 & 4.1 & 0.2 \\
\hline ardiff & 1.6 & 2.1 & -0.6 & 7.5 & 5.0 & 2.6 & 5.0 & 5.8 & -0.8 & 1.0 & -0.3 & 0.5 & 0.6 & -0.2 & 15.6 & 14.8 & 0.8 \\
\hline soment 1 & 3 & 1 . & 0.3 & 1.1 & 1.7 & -0.6 & 2.0 & 1.8 & 0.3 & 1.3 & 0.6 & 0.6 & 0.4 & 0.2 & .3 & 5.5 & 0.8 \\
\hline 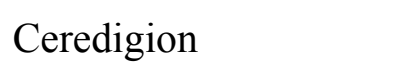 & 7 & 0 & 0.2 & 2.6 & 2.4 & 0.2 & 1.3 & 1 & .3 & 0.9 & 0.4 & 0.4 & 0.4 & 0.0 & 8 & 5.4 & 4 \\
\hline 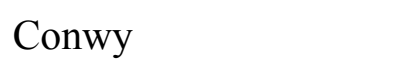 & 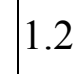 & 0 & 02 & 0.8 & 1.2 & -0.4 & 9 & 1.7 & 0.2 & 1.50 .7 & 0.8 & 0.8 & 0.6 & 0.3 & 6.2 & 5.0 & 1.2 \\
\hline ophion & 1.2 & 0.8 & 0.4 & 0.8 & 0.9 & -0.1 & 1.7 & 1.4 & 0.3 & 1.00 .6 & 0.4 & 0.6 & 0.4 & 0.1 & 5.3 & 4.2 & 1.1 \\
\hline lintshire & 1.3 & 1.0 & 0.3 & 1.0 & 1.1 & -0.2 & 2.4 & 1.8 & 0.5 & 0.80 .7 & 0.1 & 0.4 & 0.4 & 0.0 & 5.8 & 5.1 & 0.7 \\
\hline wynedd & 0.9 & 0.9 & 0.0 & 2.0 & 1.9 & 0.1 & 1.7 & 1.8 & -0.2 & 1.10 .7 & 0.4 & 0.5 & 0.5 & 0.0 & 6.2 & 5.9 & 0.3 \\
\hline sle of Ang & 0.5 & 0.6 & -0.1 & 0.4 & 0.7 & -0.3 & 0.8 & 1.0 & -0.2 & 0.60 .5 & 0.1 & 0.3 & 0.3 & 0.0 & 2.6 & 3.1 & -0.5 \\
\hline & & & & & & & & & & & & 0.1 & 0.1 & -0.1 & 1.1 & 1.4 & -0.3 \\
\hline & & & & 0.7 & 1.0 & -0.3 & & 1 & & & & 0.4 & 0.3 & 0.1 & 4.7 & 3.9 & 0.8 \\
\hline & & & 0.2 & 0.7 & 0.9 & -0.2 & 1.4 & 1.3 & 0.2 & & & 0.2 & 0.3 & 0.0 & 3.7 & 3.6 & 0.2 \\
\hline & 1.0 & & 0.1 & 0.9 & 1.2 & -0.3 & 1.8 & & 0.0 & & & 0.3 & 0.3 & 0.0 & 4.6 & 4.7 & -0.2 \\
\hline temotonest & 1.0 & & 0.3 & 0.7 & 1.1 & -0.5 & 1.4 & 1.0 & 0.4 & 1.00 .5 & 0.5 & 0.4 & 0.4 & 0.0 & 4.6 & 3.8 & 0.8 \\
\hline & 1.2 & 0.9 & 0.3 & 0.8 & 1.3 & -0.5 & 1.8 & 1.6 & 0.2 & 1.30 .8 & 0.5 & 0.7 & 0.5 & 0.2 & 5.8 & 5.1 & 0.6 \\
\hline Rhondda;Cynon;Taff & 1.0 & 1.0 & 0.0 & 1.7 & 1.9 & -0.2 & 2.0 & 2.2 & -0.3 & 0.60 .7 & 0.0 & 0.3 & 0.4 & -0.1 & 5.6 & 6.2 & -0.6 \\
\hline Swansea & 1.0 & 1.0 & 0.1 & 3.2 & 2.8 & 0.5 & 2.3 & 2.6 & -0.3 & 0.70 .6 & 0.0 & 0.3 & 0.3 & 0.0 & 7.6 & 7.3 & 0.3 \\
\hline Torfaen & 0.6 & 0.4 & 0.1 & 0.4 & 0.5 & -0.1 & 0.8 & 0.8 & 0.0 & 0.30 .3 & 0.0 & 0.1 & 0.1 & 0.0 & 2.2 & 2.2 & 0.0 \\
\hline Vale of Gla & 1.2 & 0 & 0.7 & 0.8 & 1.0 & -0.2 & 2.0 & 1.6 & 0.4 & 0.80 .5 & 0.2 & 0.5 & 0.3 & 0.2 & 5.4 & 4.4 & 1.0 \\
\hline Nrexham & 0.7 & 0.7 & 0.0 & 1.0 & 1.1 & -0.1 & 1.5 & 1.3 & 0.2 & 0.60 .5 & 0.0 & 0.3 & 0.2 & 0.1 & 4.1 & 3.9 & 0.2 \\
\hline WALES & & - & 2.5 & - & - & -1.4 & & & 1.2 & & 4.0 & & & 0.8 & - & & 7.0 \\
\hline
\end{tabular}

Source: NHSCR

Notes:

1. $\quad \mathrm{I}=$ Inflow from areas outside the UA; $\mathrm{O}=$ Outflow to areas outside the UA; Net $=$ Net migration .

2. $\quad$ Figures are in thousands.

3. Valley UAs in bold. 
TABLE 9

Age Structure of Welsh Migrant Groups: 1990-91

\begin{tabular}{|c|c|c|c|c|c|c|c|c|}
\hline & \multicolumn{6}{|c|}{ All Ages } & \multicolumn{2}{|c|}{ Working Age } \\
\hline & $0-15$ & $16-30$ & 31-50 & $>\mathbf{5 0}$ & Ave. & $\mathbf{N}$ & Ave. & $\mathbf{N}$ \\
\hline Non-mover & 20.95 & 16.11 & 27.45 & 35.48 & 40.01 & 50101 & 39.64 & 28660 \\
\hline Moved within Wales & 21.26 & 42.83 & 21.52 & 14.39 & 29.82 & 3495 & 30.48 & 2404 \\
\hline $\begin{array}{l}\text { Moved in from } \\
\text { elsewhere in Britain }\end{array}$ & 18.31 & 39.54 & 26.46 & 15.69 & 30.97 & 650 & 33.08 & 488 \\
\hline $\begin{array}{l}\text { Moved in from } \\
\text { outside Britain }\end{array}$ & 23.87 & 36.77 & 27.10 & 12.26 & 28.35 & 155 & 32.66 & 111 \\
\hline $\begin{array}{l}\text { Moved from Wales to } \\
\text { other parts of Britain }\end{array}$ & 17.63 & 49.42 & 21.25 & 11.70 & 28.74 & 607 & 29.29 & 453 \\
\hline
\end{tabular}

Source: 1991 Sample of Anonymised Records (SARs), 2\% individual sample

Notes

1. Table reports the percentage in each age category and the mean age for all individuals, whereas only the average age is reported for working age individuals (i.e. those aged 16-64 for males and 16-59 for females).

2. Those individuals who stated that their main economic position was a student are excluded.

TABLE 10

Human Capital Characteristics of Welsh Migrant Groups: 1990-91

\begin{tabular}{|c|c|c|c|c|c|c|}
\hline & \multicolumn{3}{|c|}{ Higher qualifications } & \multicolumn{3}{|c|}{ Social Class } \\
\hline & None & One & $\begin{array}{l}\text { Two or } \\
\text { more }\end{array}$ & $\begin{array}{l}\text { Prof./ } \\
\text { Man. }\end{array}$ & Skilled & $\begin{array}{c}\text { Partly/ } \\
\text { Unskilled }\end{array}$ \\
\hline Non-mover & 86.80 & 8.13 & 5.07 & 28.24 & 45.01 & 26.75 \\
\hline Moved within Wales & 85.94 & 9.23 & 4.83 & 26.11 & 46.29 & 27.59 \\
\hline $\begin{array}{l}\text { Moved in from } \\
\text { elsewhere in the UK }\end{array}$ & 70.29 & 19.06 & 10.66 & 44.63 & 32.94 & 22.43 \\
\hline $\begin{array}{l}\text { Moved in from } \\
\text { outside the UK }\end{array}$ & 73.87 & 18.02 & 8.11 & 51.32 & 38.16 & 10.53 \\
\hline $\begin{array}{l}\text { Moved from Wales to } \\
\text { other parts Britain }\end{array}$ & 62.91 & 23.40 & 13.69 & 49.73 & 35.56 & 14.71 \\
\hline
\end{tabular}

Source: SARS

Notes:

1. Table reports the percentage of individuals with no, 1 or 2 or more higher qualifications and in each social class for working age individuals, other than current students.

2. Higher qualifications are post-school qualifications e.g. degree, vocational and professional qualifications. 
TABLE 11

Highest Educational Qualification by Country of Residence and Country of Birth: 2003

\begin{tabular}{lcccccc}
\hline & $\begin{array}{c}\text { Welsh } \\
\text { born } \\
\text { living in } \\
\text { Wales }\end{array}$ & $\begin{array}{c}\text { Non-Welsh } \\
\text { born living } \\
\text { in Wales }\end{array}$ & $\begin{array}{c}\text { Welsh born } \\
\text { living in } \\
\text { other parts } \\
\text { of UK }\end{array}$ & $\begin{array}{c}\text { Non-Welsh } \\
\text { born living } \\
\text { in other } \\
\text { parts of UK }\end{array}$ & $\begin{array}{c}\text { Works in } \\
\text { Wales } \\
\text { and lives } \\
\text { elsewhere } \\
\text { in UK }\end{array}$ & $\begin{array}{c}\text { Lives in } \\
\text { Wales and } \\
\text { works } \\
\text { elsewhere } \\
\text { in UK }\end{array}$ \\
\hline $\begin{array}{l}\text { Degree } \\
\text { Higher }\end{array}$ & 11.06 & 23.47 & 33.15 & 15.88 & 30.77 & 23.31 \\
education & 7.97 & 9.34 & 12.08 & 8.59 & 9.23 & 11.02 \\
A Level & 22.90 & 24.28 & 20.44 & 23.85 & 23.08 & 24.15 \\
GCSE/ & 24.97 & 19.32 & 16.71 & 21.95 & 16.92 & 21.19 \\
O Level & 12.49 & 10.45 & 8.36 & 13.69 & 13.08 & 10.17 \\
Other & 20.62 & 13.13 & 9.26 & 16.05 & 6.92 & 10.17 \\
None & 4341 & 1713 & 1101 & 115484 & 130 & 236 \\
\hline $\mathrm{N}$ & & & & & & \\
\hline
\end{tabular}

Source: $L F S$

Notes:

1. Table reports column percentages using unweighted data.

2. The data are obtained by pooling four quarters of the LFS from December 2002November 2003. Only those respondents in their first or last wave are included in the table.

3. The table consists only of people of working age. 
TABLE 12

Multinomial Logit Estimates of Migration: 1990-91

\begin{tabular}{lcccc}
\hline & Non-mover & $\begin{array}{c}\text { Moved } \\
\text { within Wales }\end{array}$ & $\begin{array}{c}\text { Moved in } \\
\text { from other } \\
\text { UK }\end{array}$ & $\begin{array}{c}\text { Moved in } \\
\text { from outside } \\
\text { UK }\end{array}$ \\
\hline Female & $-0.002(0.02)$ & $0.037(0.32)$ & $0.064(0.44)$ & $-0.086(0.37)$ \\
Age & $0.084(11.48)$ & $-0.001(0.19)$ & $0.026(2.69)$ & $0.038(2.59)$ \\
Higher qualifications & $-1.773(14.95)$ & $-1.427(10.83)$ & $-0.486(3.01)$ & $-0.619(2.25)$ \\
Unemployed & $-0.434(2.63)$ & $-0.143(0.82)$ & $0.185(0.84)$ & $0.617(1.86)$ \\
Inactive & $-0.188(1.12)$ & $0.108(0.61)$ & $-0.045(0.20)$ & $0.506(1.61)$ \\
Married & $-0.064(0.45)$ & $0.196(1.27)$ & $-0.012(0.06)$ & $-0.032(0.10)$ \\
Divorced / Widowed & $-0.462(2.05)$ & $0.433(1.82)$ & $0.092(0.31)$ & $-0.528(0.97)$ \\
1 or more dependant & $0.850(6.90)$ & $0.356(2.67)$ & $0.034(0.20)$ & $0.211(0.80)$ \\
children & & & & $1.068(2.27)$ \\
Non-white & $-0.867(2.61)$ & $-0.352(1.03)$ & $-0.045(0.10)$ & $-2.575(5.75)$ \\
Constant & $1.620(8.14)$ & $1.921(9.01)$ & $-0.600(2.20)$ & -2613 \\
\hline N & 24108 & 2232 & 413 & 96 \\
\hline
\end{tabular}

Source: SARs

Notes:

1. Table reports coefficients and heteroscedastic consistent $t$-statistics in parentheses.

2. The table consists of only individuals aged between 18 and 55, who are not students.

3. Reference individual is an employed, white, single, male with no higher qualifications or dependant children.

4. The base category is moved to outside Wales. The sample size for this category is 382 . 
TABLE 13

Average Willingness to Move by Demographic Sub-Group, Britain: 1995

\begin{tabular}{|c|c|c|c|c|c|c|}
\hline & $\begin{array}{c}\text { Neighbour- } \\
\text { hood }\end{array}$ & $\begin{array}{c}\text { Town/ } \\
\text { City }\end{array}$ & County & Country & Continent & 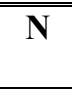 \\
\hline \multicolumn{7}{|l|}{ Gender } \\
\hline Male & 3.63 & 3.39 & 3.08 & 2.60 & 2.35 & 262 \\
\hline Female & 3.57 & 3.18 & 2.83 & 2.37 & 2.20 & 371 \\
\hline p-value (male/female) & 0.549 & 0.050 & 0.023 & 0.050 & 0.179 & 631 \\
\hline \multicolumn{7}{|l|}{ Age } \\
\hline $18-35$ & 3.78 & 3.32 & 3.03 & 2.58 & 2.42 & 325 \\
\hline $36-55$ & 3.41 & 3.21 & 2.83 & 2.34 & 2.09 & 308 \\
\hline p-value (18-35/36-55) & 0.000 & 0.303 & 0.064 & 0.032 & 0.004 & 631 \\
\hline \multicolumn{7}{|l|}{ Qualifications } \\
\hline Higher education & 3.60 & 3.36 & 3.15 & 2.80 & 2.53 & 179 \\
\hline No higher education & 3.59 & 3.23 & 2.85 & 2.33 & 2.15 & 454 \\
\hline p-value (higher/none) & 0.939 & 0.269 & 0.017 & 0.000 & 0.003 & 631 \\
\hline \multicolumn{7}{|l|}{ Occupation } \\
\hline Non-manual & 3.64 & 3.30 & 3.05 & 2.59 & 2.39 & 363 \\
\hline Manual & 3.57 & 2.26 & 2.81 & 2.30 & 2.10 & 246 \\
\hline p-value (non-man./man.) & 0.523 & 0.753 & 0.034 & 0.014 & 0.014 & 607 \\
\hline \multicolumn{7}{|l|}{ Economic position } \\
\hline Unemployed & 3.79 & 3.49 & 3.04 & 2.62 & 2.28 & 53 \\
\hline Employee & 3.63 & 3.32 & 3.00 & 2.57 & 2.38 & 437 \\
\hline Inactive & 3.39 & 2.99 & 2.64 & 1.98 & 1.82 & 143 \\
\hline p-value (unemp./emp.) & 0.364 & 0.360 & 0.852 & 0.809 & 0.658 & 509 \\
\hline p-value (unemp./inact.) & 0.080 & 0.034 & 0.096 & 0.006 & 0.034 & 173 \\
\hline p-value (inact./emp.) & 0.073 & 0.015 & 0.011 & 0.000 & 0.000 & 578 \\
\hline \multicolumn{7}{|l|}{ Housing Tenure } \\
\hline Private renting & 3.72 & 3.53 & 3.29 & 2.97 & 2.79 & 76 \\
\hline Social housing & 3.64 & 3.25 & 2.70 & 2.22 & 2.09 & 132 \\
\hline Owner occupied & 3.56 & 3.23 & 2.94 & 2.44 & 2.21 & 425 \\
\hline p-value (renting/social) & 0.668 & 0.159 & 0.005 & 0.001 & 0.001 & 206 \\
\hline p-value (renting/OO) & 0.306 & 0.071 & 0.043 & 0.003 & 0.001 & 499 \\
\hline p-value (social/OO) & 0.513 & 0.883 & 0.076 & 0.107 & 0.359 & 555 \\
\hline \multicolumn{7}{|l|}{ Area } \\
\hline Wales & 3.43 & 3.45 & 2.95 & 2.75 & 2.60 & 40 \\
\hline North England & 3.65 & 3.27 & 2.84 & 2.35 & 2.12 & 256 \\
\hline South England & 3.60 & 3.29 & 3.06 & 2.55 & 2.36 & 281 \\
\hline Scotland & 3.46 & 3.09 & 2.73 & 2.34 & 2.18 & 56 \\
\hline p-value (Wales/North England) & 0.313 & 0.415 & 0.499 & 0.091 & 0.041 & 294 \\
\hline p-value (Wales/South England) & 0.405 & 0.454 & 0.480 & 0.422 & 0.330 & 319 \\
\hline p-value (Wales/Scotland) & 0.892 & 0.212 & 0.476 & 0.190 & 0.170 & 94 \\
\hline Great Britain & 3.60 & 3.27 & 2.93 & 2.46 & 2.26 & 633 \\
\hline
\end{tabular}

Source: British Social Attitudes Survey (BSAS)

Notes:

1. The table only includes those observations in which the individual answered all of the WTM questions.

2. The regional identifier in the $B S A S$ is a Standard Statistical Region. North England = North West, North East, Yorkshire \& Humberside, East and West Midlands. South England = South East, South West, London and East Anglia.

3. $\mathrm{p}$-value refers to a two-tailed test of the difference between the two mean WTM values in parentheses. $\mathrm{N}$ in this instance gives to the number of degrees of freedom used in the test. 


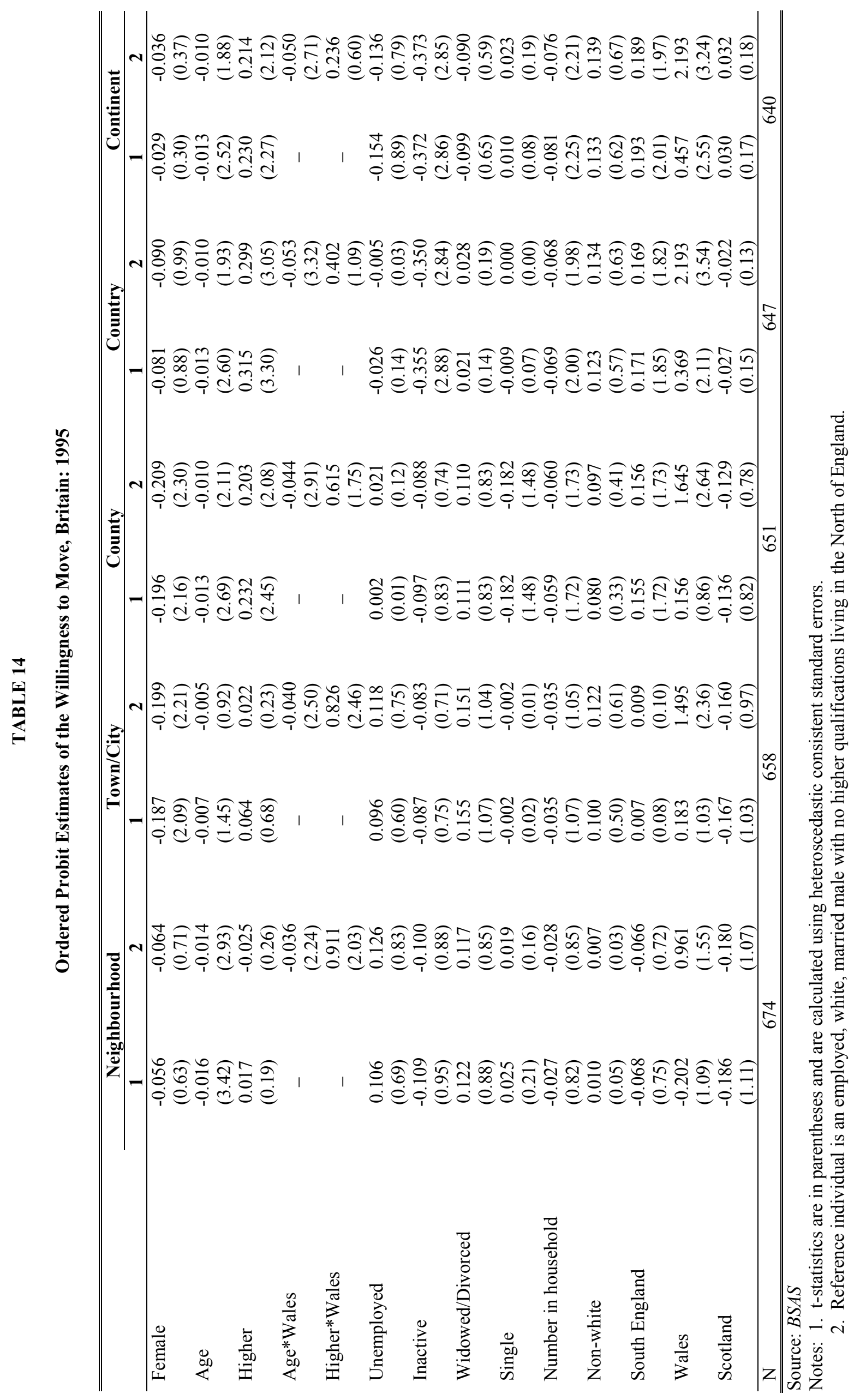




\section{FIGURE 1}

Unitary Authorities in Wales

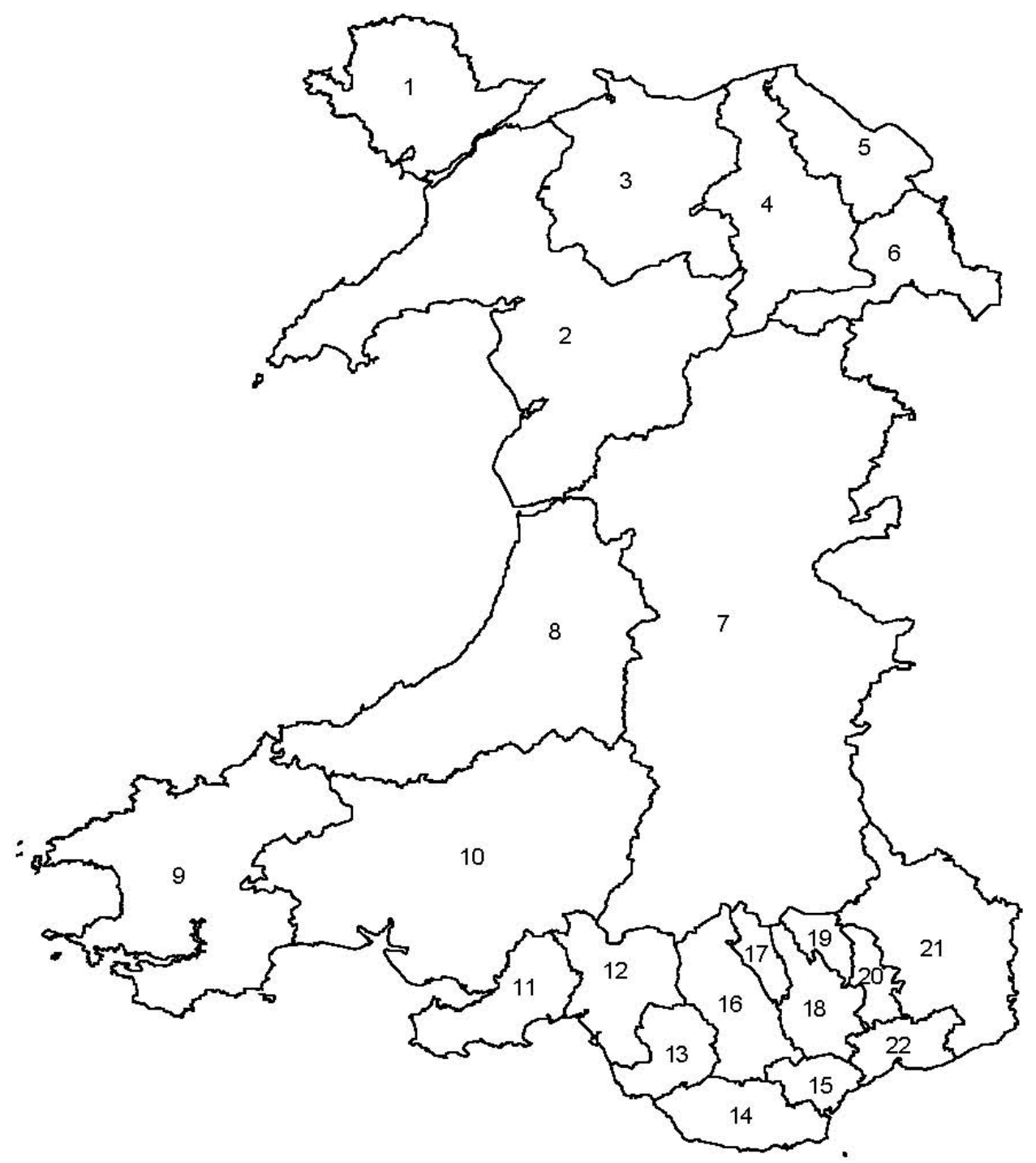

1 Isle of Anglesey 12 Neath \& Port Talbot

2 Gwynedd

13 Bridgend

3 Conwy

14 Vale of Glamorgan

4 Denbighshire

15 Cardiff

5 Flintshire

16 Rhondda Cynon Taff

6 Wrexham

17 Merthyr Tydfil

7 Powys

18 Caerphilly

8 Ceredigion

19 Blaenau Gwent

9 Pembrokeshire

20 Torfaen

10 Carmarthenshire 21 Monmouthshire

11 Swansea

22 Newport 


\section{Appendix}

The WTM questions asked in the BSAS were:

- If you could improve your work or living conditions, how willing or unwilling would you be to move to another neighbourhood or village?

1. Very willing (recoded as 5)

2. Fairly willing (recoded as 4)

3. Neither willing nor unwilling (coded as 3 )

4. Fairly unwilling (recoded as 2)

5 . Very unwilling (recoded as 1 )

- If you could improve your work or living conditions, how willing or unwilling would you be to move to another town or city within this county?

1. Very willing (recoded as 5)

2. Fairly willing (recoded as 4)

3. Neither willing nor unwilling (coded as 3 )

4. Fairly unwilling (recoded as 2)

5 . Very unwilling (recoded as 1 )

- If you could improve your work or living conditions, how willing or unwilling would you be to move to another county?

1. Very willing (recoded as 5)

2. Fairly willing (recoded as 4)

3. Neither willing nor unwilling (coded as 3 )

4. Fairly unwilling (recoded as 2)

5 . Very unwilling (recoded as 1 )

- If you could improve your work or living conditions, how willing or unwilling would you be to move outside Britain?

1. Very willing (recoded as 5)

2. Fairly willing (recoded as 4)

3. Neither willing nor unwilling (coded as 3 )

4. Fairly unwilling (recoded as 2)

5 . Very unwilling (recoded as 1 )

- If you could improve your work or living conditions, how willing or unwilling would you be to move outside Europe?

1. Very willing (recoded as 5)

2. Fairly willing (recoded as 4)

3. Neither willing nor unwilling (coded as 3 )

4. Fairly unwilling (recoded as 2)

5 . Very unwilling (recoded as 1 ) 